九州大学学術情報リポジトリ

Kyushu University Institutional Repository

\title{
New Turrid Taxa from the Austrarian waters
}

Shuto, Tsugio

Faculty of Science, Kyushu University

https://doi.org/10.5109/1546082

出版情報：九州大學理學部紀要：Series D, Geology. 25 (1)，pp.1-26，1983-11-15. Faculty of Science, Kyushu University バージョン :

権利関係 : 
Mem. Fac. Sci., Kyushu Univ., Ser. D, Geol., Vol. XXV, No. 1, pp. 1-26, text-figs. 1-7, plates 1-2, November 15,1983

\title{
New Turrid Taxa from the Austrarian waters
}

\author{
Tsugio SHUTO
}

\begin{abstract}
New turrid taxa, including three new genera, five new subgenera and thirteen new species, are described on the basis of specimens stored in the Australian Museum, Sydney. Thirteen species out of fifteen total species came from the tropical or subtropical Australian waters and the remaining two from the temperate waters off Sydney.
\end{abstract}

Through July into August, 1982, I had the opportunity to look over turrid specimens stored in the Department of Malacology, the Australian Museum by the courtesy of the authorities of the Museum. On that occasion, several minute species appeared to be new to science. Most of them had been proved to be new taxa after minute examination. This is the first part of the descriptive report of those taxa and includes Paradrillia (Coronacomitas) gemmata subgen. et sp. nov., $P .(P)$ darnleyensis sp. nov., Ariella (Vexiariella) cancellata subgen. et sp. nov., Vexithara brevicanalis sp. nov., Horaiclavus (Anguloclavus) multicostatus (SchePMAN) subgen. nov., Graciliclava mackayensis gen. et sp. nov., Euryentmena australiana sp. nov., Antiguraleus stellatomoides sp. nov., Austropusilla (Metaclathurella) crokerensis subgen. et sp. nov., Philbertia (Glyphostomoides) queenslandica subgen. et sp. nov., Vepridaphne cestrum (HEDLEY), gen, nov., Tritonoturris buccinoides sp. nov., Pagodidaphne colmani gen. et sp. nov., Austrodaphnella torresensis sp. nov. and Pseudexomilus bicarinatus sp. nov.

Here I would express my cordial thanks to Drs. W. F. Ponder and W. B. RUDMAN for their effective arrangement of access to the necessary material and also for their kind assistance in the study.

\section{Systematics}

Family Turridae

Subfamily Turriculinae

genus Paradrillia MaKIYAMA, 1940

type-species: Drillia dainichiensis Yokoyama, (o. d.)

subgenus Coronacomitas subgen. nov.

type-species: Paradrillia (Coronacomitas) gemmata subgen.

et sp. nov.

Diagnosis.-Shell moderately small, solid and biconically fusiform with moderately high spire and gradually tapered base. Protoconch paucispiral consisting of depressed, round and smooth first volution and sharply carinate second 
one. Teleoconch sculpture of gemmulate peripheral and subsutural cords and coarse cancellation on basal surface, i. e. a combined sculpture of Gemmula Weinkauff, 1875 and Paradrillia Makiyama, 1940. Anal sinus moderately deep and asymmetrically $\mathrm{v}$-shaped with apex on the boundary between subsutural sulcus and peripheral cord. Aperture elongately pyriform with moderately long, oblique and terminally truncated canal. Labrum lirate inside; parietal callus thick.

Comparison.-The present taxon is featured by its teleoconch with a combined sculpture of Gemmula and Paradrillia and by protoconch similar to Paradrillia. It is similar to certain genera of Borsoniinae such as Micantapex IREDALE, 1936, with its solid and biconic shell and particular sculpture mentioned above, but the former is devoid of any columellar fold.

It differs from Comitas Finlay, 1926, in the position of anal sinus and sculptural pattern.

It is the closest to Paradrillia MakiYama, 1940, both in the protoconch and teleoconch, but is clearly distinguished from the major species of Paradrillia by the anal sinus. The anal sinus of the present taxon with horizontally stretching upper arm and broadly curving lower one is deeper and more asymmetric than that of the latter. Furthermore, the apex of the sinus is situated at the boundary between the subsutural sulcus and peripheral cord on the present taxon instead at the subsutural sulcus on major species of Paradrillia. Concerning the last mentioned feature, the present taxon is close to Paradrillia serana (FISCHER) and they must comprise one particular group in Paradrillia (s. 1.) sharing com-
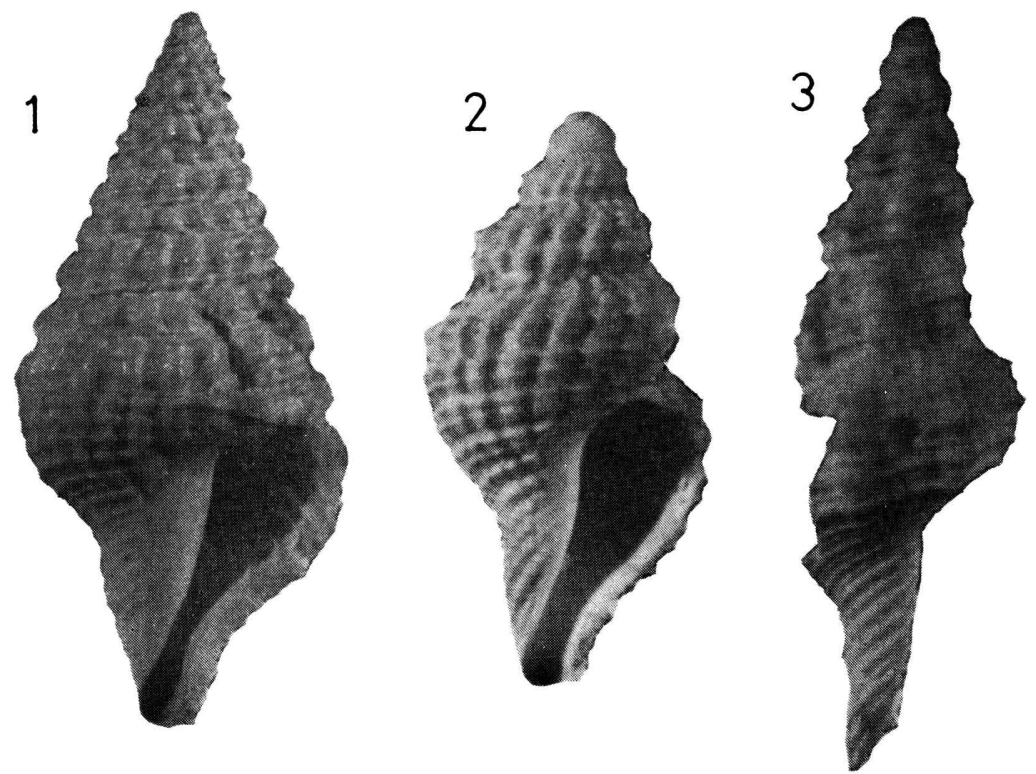

Fig. 1. Australian turrids 1. Paradrillia (Coronacomitas) gemmata subgen. et sp. nov., holotype, C 134694a, front view, $\times 5.6$. 2. Euryentmena australiana sp. nov., holotype, C 134678, front view, $\times 12.9$. 3. Vepridaphne cestrum (HEDlEY), gen. nov., C, 134683, side view, $\times 7.0$. 
mon features in protoconch, sculpture and anal sinus.

Characteristic species.-Paradrillia (Coronacomitas) gemmata subgen. et sp. nov., northern Australia; $P$. (C.) serana (FISCHER), Pliocene of seram, Indonesia and Panay, the Philippines.

Paradrillia (Coronacomitas) gemmata subgen. et sp. nov.

PI. 2, Fig. 7, Text-figs. 1 and 2

Material.-holotype: C 134694a, and paratype C 134694b. Both from approximately 100 miles north of Croker Island $\left(9^{\circ} 30^{\prime} \mathrm{S}, 132^{\circ} 34^{\prime} \mathrm{E}\right)$, Northern Teritory, Australia. P. H. Colman coll., Nov. 9, 1969.

\begin{tabular}{lcccccccc}
\multicolumn{2}{c}{ Measurements.- } & & & & & \\
specimen & $\mathrm{H}$ & $\mathrm{Bd}$ & $\mathrm{W}$ & $\mathrm{Bd} / \mathrm{H}$ & $\mathrm{W} / \mathrm{H}$ & $\begin{array}{c}\text { protoconch } \\
\text { vols. }\end{array}$ & $\begin{array}{c}\text { teleoconch } \\
\text { whorls }\end{array}$ \\
C 134694a & 12.95 & 7.65 & 6.05 & 59.1 & 46.7 & 1.9 & 0.7 & 7.0 \\
C 134694b & 9.15 & 5.50 & 4.25 & 60.1 & 46.4 & 1.9 & 0.7 & 6.2
\end{tabular}

Diagnosis.-Diagnostic feature is the same as the subgeneric diagnosis.

Description.-C 134694 comprises two specimens, which quite conform to each other in the morphological feature except for size.

Shell is thick, solid and biconic with straight-sided, moderately high spire and equally long tapered base. Protoconch is paucispiral with about two volutions. Tip is depressed, early one and a third volutions are low, round and smooth and the remainder part is sharply carinated at lower two-fifths. A few opisthocyrtly curved weak brephic axials may be present above carina on the last part. Boundary between the protoconch and teleoconch is sharp, indicated by abrupt disappearance of the carina and appearance of opisthocyrt axial ribs which connect two spiral cords, one close to the upper suture and the other at the lower fouth. Teleoconch of the holotype consists of seven whorls. The first whorl is provided with 11 axial ribs, of which the first one is strong but simple. The following axials are progressively accentuated with granular swell both at upper and lower ends, and then the granules are laterally connected by spiral cords. Lower (peripheral) set of cord and granules is much heavier than the subsutural one. Area between the two sets abruptly develops into an infrasutural sulcas in association with weakening of axials on that part. Peripheral cord is bipartited by a shallow groove on the third and later whorls so that each granule is differentiated into upper and lower swells by a median saddle, although the superjacent groove hardly crosses over granules. A weak spiral thread appears respectively on the infrasutural sulcus and between the lower suture and peripheral cord on the third whorl. The latter (suprasutural lira) is increased in its relative size later. Body whorl, occupying 60 percent of the height of the shell, is moderately contracted between the round base and straight snout. Basal surface is covered with cancellation of distinct spiral cords and axial riblets with granules at intersections. Snout is provided with distinct, oblique and simple spiral lirae. Aperture is moderately wide, differentiated into rhomboid aperture proper and moderately long, widely open and terminally truncated canal. Inner lip is covered with callus, which is particularly thick on the columellar part and 
shows minute striation. Anal sinus is moderately deep, asymmetrically v-shaped with horizontally stretching upper arm and broadly curving lower arm. The upper arm is then turned upward to merge to the upper suture with an angle of about 80 degrees. Apex of the sinus is situated at the border area between the infrasutural sulcus and peripheral cord.

Comparison.-The present species is superficially similar to shorter forms of Gemmula, but is readily distinguished from the latter by clear difference in protoconch and anal sinus.

It resembles Paradrillia serana (FISCHER) from the Pliocene of Seram, Indonesia (FISCHER, 1927, p. 34, pl. 78, fs. 71a and b) in the general facies, but the former has shorter shell with stouter scupture, otherwise they conform to each other.

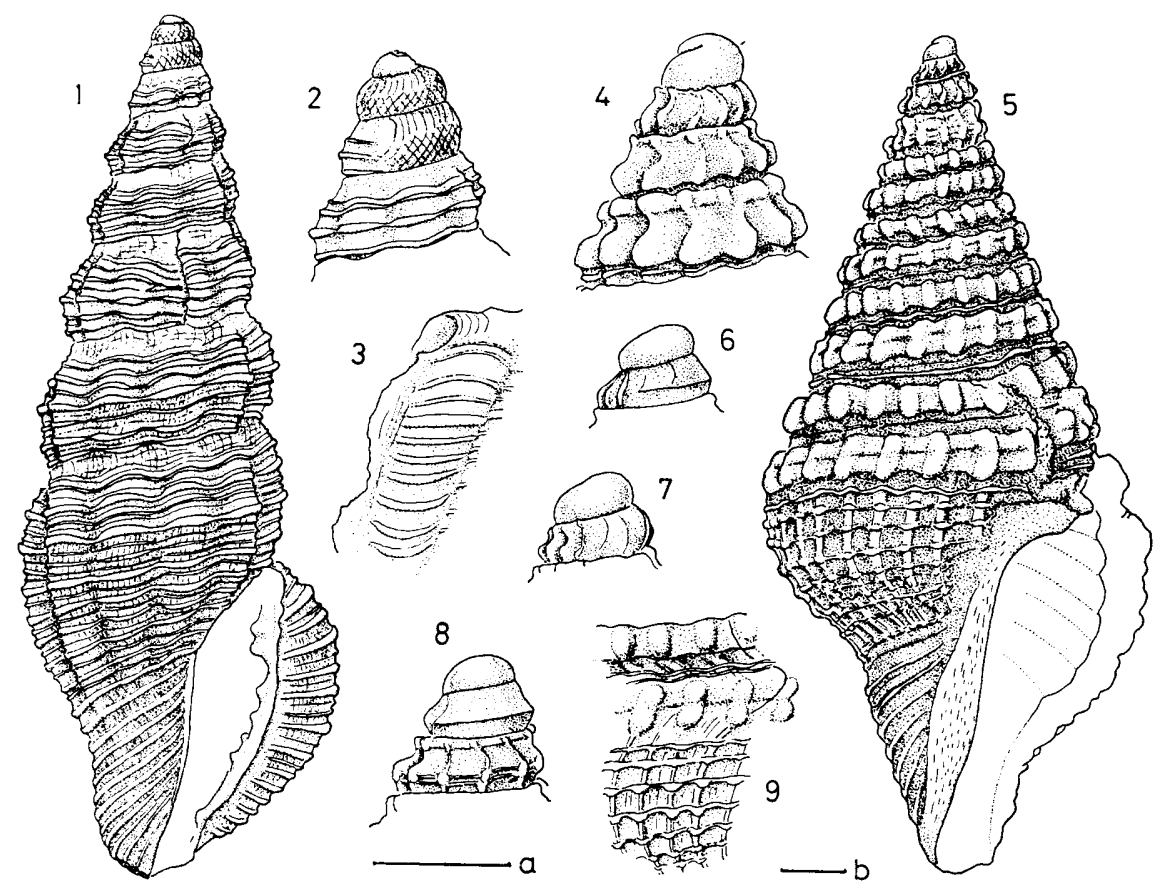

Fig. 2. Australian turrids 1-3. Philbertia (Glyphostomoides) queenslandica subgen. et sp. nov., holotype, C 134681, front view (1), protoconch (2) and anal sinus (3). 4-9. Paradrillia (Coronacomitas) gemmata subgen. et sp. nov., holotype, C 134694a, front view (5), apical part (4), protoconch (6) and part of sculpture (9). paratype, C $134694 \mathrm{~b}$, protoconch (7 and 8). Scale bar a $1 \mathrm{~mm}$ for $1,3,4,6,7,8$ and $9 ; 0.5 \mathrm{~mm}$ for 2 . Scale bar b $1 \mathrm{~mm}$ for 5 .

subgenus Paradrillia Makryama, 1940

Paradrillia (Paradrillia) darnleyensis sp. nov.

Pl. 1, Figs. 7 and 8 , Text-fig. 3

Material.-Holotype: C 61502 from Darnley Island, Torres Strait, Queensland. Depth, 40-55 m. 


\begin{tabular}{|c|c|c|c|c|c|c|c|}
\hline specimen & $\underset{(\mathrm{mm})}{\mathrm{H}}$ & $\underset{(\mathrm{mm})}{\mathrm{Bd}}$ & $\underset{(\mathrm{mm})}{\mathrm{W}}$ & $\begin{array}{c}\mathrm{Bd} / \mathrm{H} \\
(\%)\end{array}$ & $\begin{array}{l}\mathrm{W} / \mathrm{H} \\
(\%)\end{array}$ & $\begin{array}{c}\text { protoconch } \\
\text { vols. } D(\mathrm{~mm})\end{array}$ & $\begin{array}{l}\text { teleoconch } \\
\text { whorls }\end{array}$ \\
\hline C 61502 & 11.80 & 5.70 & 4.55 & 48.3 & 38.5 & $1.8 \quad 0.6$ & 8.0 \\
\hline
\end{tabular}

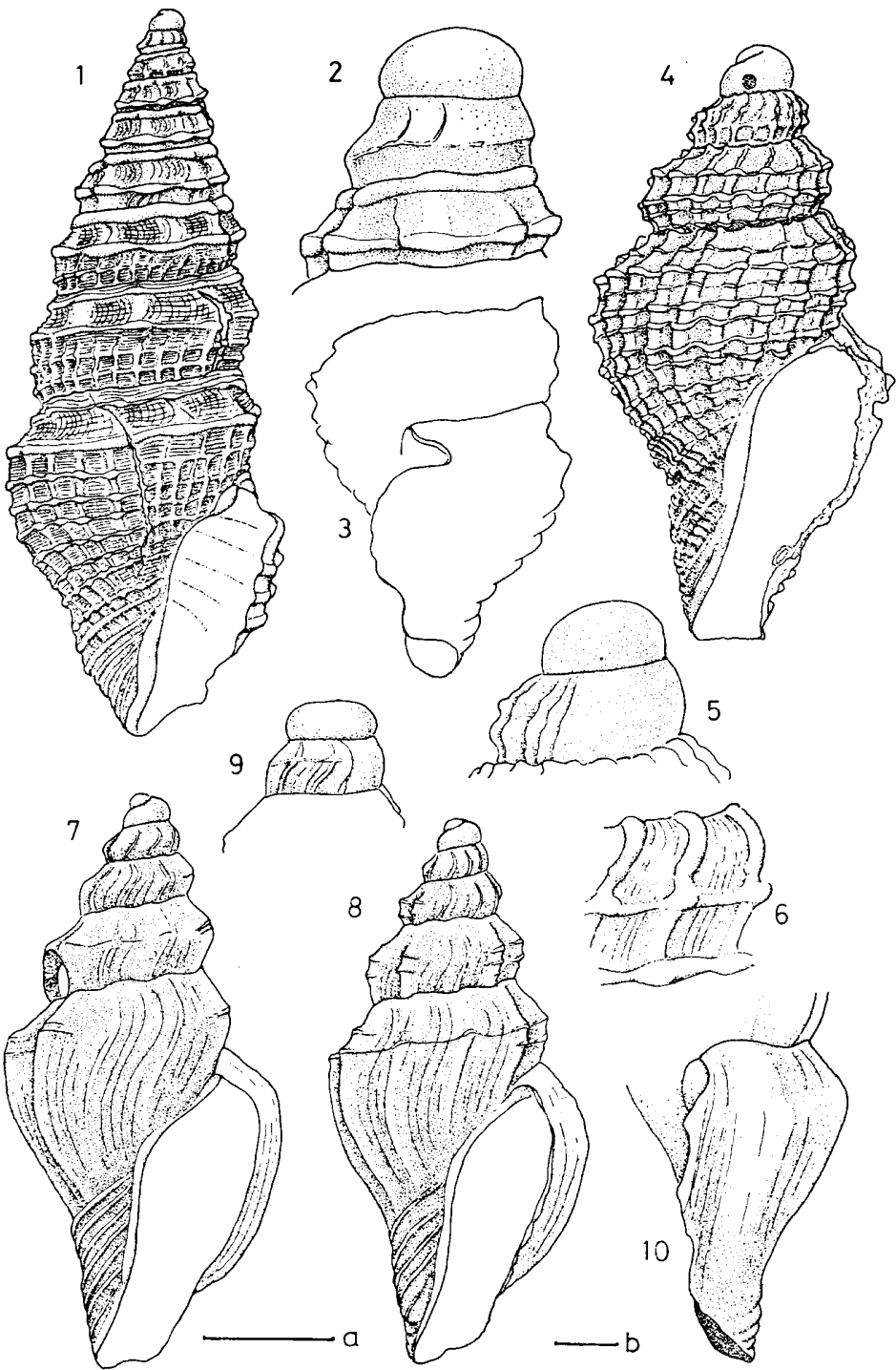

Fig. 3. Australian turrids 1-3. Paradrillia (Paradrillia) darnleyensis sp. nov. holotype, C 61502, front view (1), protoconch (2) and body whorl showing anal sinus (3). 4-6. Euryentmena australiana sp. nov. holotype, C 134678, front view (4), protoconch (5) and sculptural pattern on the upper part of the body whorl (6). 7-10. Antiguraleus stellatomoides sp. nov. holotype, C 134686a, front view (7) and anal sinus (10); paratype, C $134686 \mathrm{~b}$, front view (8) and protoconch (9). Scale bar a $1 \mathrm{~mm}$ for 4 and $9 ; 0.5 \mathrm{~mm}$ for 2,5 and 6 . Scale bar b $1 \mathrm{~mm}$ for $1,3,7,8$ and 10 . 
Diagnosis.-Shell small, solid and claviform. Protoconch paucispiral, globose and smooth except for carinate last part. Teleoconch-whorls peripherally angulate. Sculpture of prominent subsutural and peripheral cords and distantly spaced crude axial ribs above peripheral angulation and irregular cancellation below angulation. Aperture rhomboid with short, widely open and obliquly truncated canal. Anal sinus deep with its apex close to peripheral cord. Parietal callus thick. Labrum spirally lirate inside.

Remarks and comparison.-Paradrillia MAKIYAMA, 1940 and Vexitomina PowELL, 1942 show a common tendency of increasing axials on the lateral surface by abrupt and irregular intercalation of several riblets. Most of those riblets do not reach the peripheral angulation. This tendency is exaggerated on the present species. Interspaces between major axials and spirals are covered with fine reticulation of growth- and spiral lines. Subsutural and peripheral cords are provided with laterally elongate nodes at intersections with axial ribs.

The present species is distinctive by the last mentioned feature and prominent substutural band among species of Paradrillia (s. s.), which have vertically elongate and closely spaced nodes on the peripheral cord and moderate subsutural cord.

Generic identification of the present species is not certain, because it lacks operculum, which is the sole basis for distinction between Paradrillia and Vextomina. However, liration inside labrum on the present species suggests probable reference to Paradrillia.

\section{Subfamily Borsoniinae genus Ariella Shasky, 1961}

type-species: Ariella mitriformis SHASKY, 1961 (o. d.) subgenus Vexiariella subgen. nov.

type-species: Ariella (Vexiariella) cancellata subgen. et sp. nov.

Diagnosis.-Shell small, solid and biconically fusiform. Protoconch relatively small, planorbid and paucispiral consisting of one and three-fourths smooth volutions. Teleoconch with regular cancellation of raised thin axials and prominent spiral cords. Intersections distinctly granular. Growthlines dense, distinct and crossing over spirals. Body whorl, occupying two-thirds of whole height, gradually tapered to undifferentiated snout. Aperture long and narrow with undifferentiated and terminally truncated canal. Labrum thin at the margin and thickened inside. Columellar plaits two. Anal sinus moderately deep, reversed L-shaped below suture with its apex on the infrasutural cord.

Comparison.-Vexiariella is included in a group of Ariella SHasky, 1961, on the basis of its paucispiral smooth planorbid protoconch, biconically fusiform teleoconch and long and narrow aperture with two columellar plaits. The former is, however, readily separated from the genus Ariella in much longer base, deeper anal sinus and thinner axials and spirals. Anal sinus is particularly evaluated to separate the present taxon from Ariella as a subgenus.

Ariella (Vexiariella) cancellate subgen. et sp. nov. Pl. 1, Figs. 11 and 12, Text-fig. 4 
Material.-holotype: C 134664 from loc. BMR-1220, $150 \mathrm{~km}$ northwest of Melville Island, Northern Teritory, Australia ( $9^{\circ} 53^{\prime} \mathrm{S}, 130^{\circ} 2^{\prime} \mathrm{E}$ ) ; depth $205 \mathrm{~m}$; substrate sand. P. H. Colman coll., Dec. 5, 1969.

\begin{tabular}{|c|c|c|c|c|c|c|c|}
\hline specimen & $\underset{(\mathrm{mm})}{\mathrm{H}}$ & $\underset{(\mathrm{mm})}{\mathrm{Bd}}$ & $\underset{(\mathrm{mm})}{\mathrm{W}}$ & $\begin{array}{c}\mathrm{Bd} / \mathrm{H} \\
(\%)\end{array}$ & $\begin{array}{l}\mathrm{W} / \mathrm{H} \\
(\%)\end{array}$ & $\begin{array}{l}\text { protoconch } \\
\text { vols. } \mathrm{D}(\mathrm{mm})\end{array}$ & $\begin{array}{l}\text { teleoconch } \\
\text { whorls }\end{array}$ \\
\hline C 134664 & 8.50 & 5.50 & 2.90 & 64.8 & 34.4 & $1.75 \quad 0.6$ & 5.3 \\
\hline
\end{tabular}

Diagnosis.-Same as the subgeneric diagnosis.

Descriptive remarks.-Boundary between the protoconch and teleoconch is sharply demarcated by a sinusigera ridge. Diameter of the first whorl of the

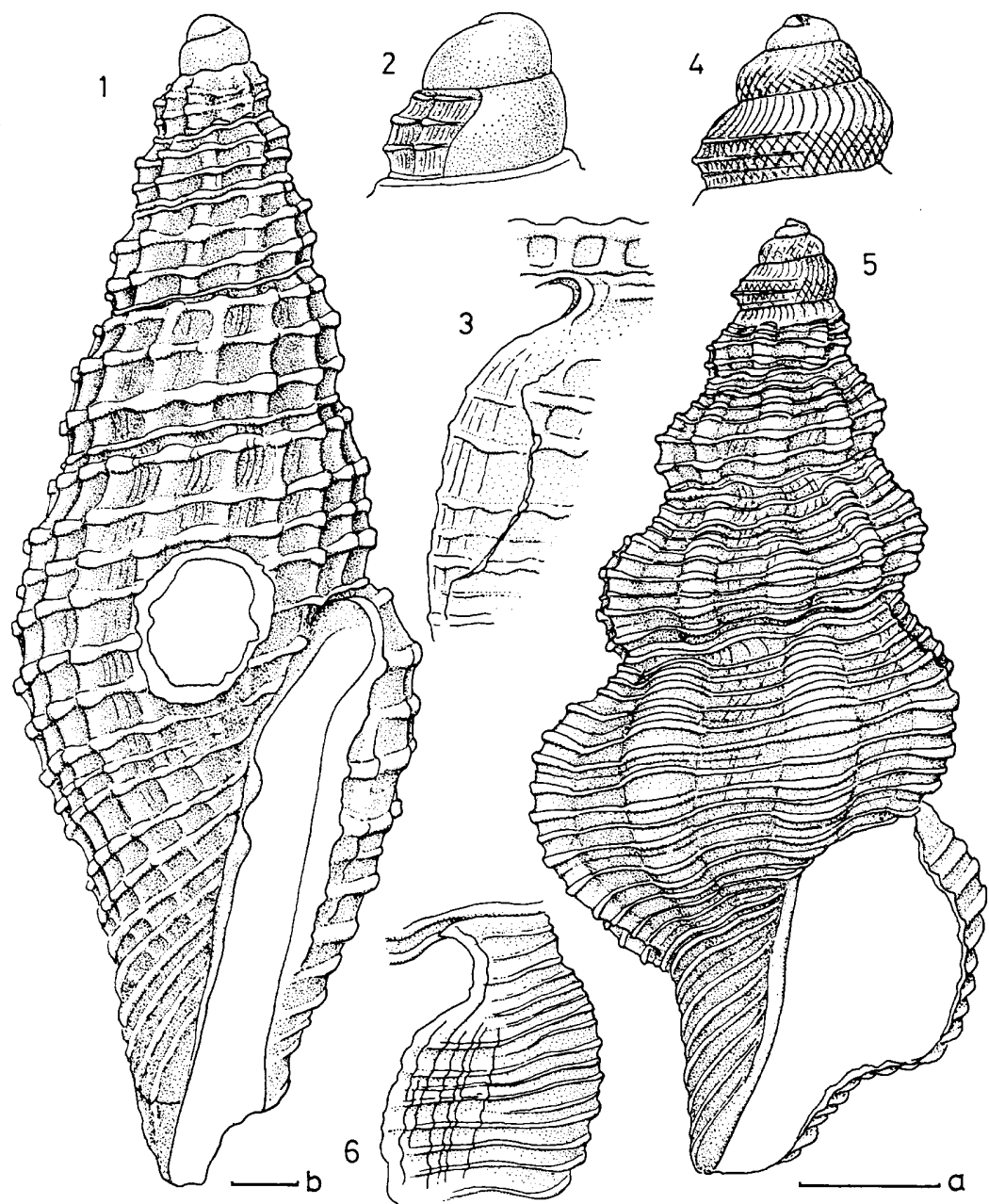

Fig. 4. Australian turrids 1-3. Ariella (Vexiariella) cancellata subgen. et sp. nov. holotype, C 134664, front view (1), protoconch (2) and anal sinus (3). 4-6. Tritonoturris buccinoides sp. nov. holotype, C 134673a, front view (5), protoconch (4) and anal sinus (6).

Scale bar a $1 \mathrm{~mm}$ for $1,3,5$ and $6 ; \mathrm{b} 0.25 \mathrm{~mm}$ for 2 and 4 . 
teleconch is more than one and a half times larger than the last volution of the protoconch. After abrupt increase in shell size at the mentioned stage, teleconch whorls increase very gradually. Base is hardly contracted. Primary spirals are three, of which the lowest one is half covered under the following whorl, as strong as axials. Axials are gradually weakened on the basal surface and faded out on the snout. Anal sinus is deep only at the last stage of growth and configuration of the former anal sinus indicated by growthlines is very shallow.

Comparison.-Ariella mitriformis SHASKY, the type-species of the genus, is only an allied species to the present species. The latter is, however, readily distinguished from the former by longer fusiform shell, thinner sculpture and deeper anal sinus.

genus Vexithara FinLAY, 1926

type-species: Antimitra vexilliformis MARShall and MURDOCH, o. d.

Vexithara brevicanalis sp. nov.

Pl. 2, Figs. 10 and 11, Text-fig. 5

Material.-holotype: C 134689 from Turtle Beach, west side of NW Cape, Western Australia. W. F. PonDer and L. FIGGIS coll., July 17, 1972. Protoconch is slightly abraded.

\section{Measurements.-}

\begin{tabular}{|c|c|c|c|c|c|c|c|}
\hline specimen & $\underset{(\mathrm{mm})}{\mathrm{H}}$ & $\underset{(\mathrm{mm})}{\mathrm{Bd}}$ & $\underset{(\mathrm{mm})}{\mathrm{W}}$ & $\underset{(\%)}{\mathrm{Bd} / \mathrm{H}}$ & $\begin{array}{l}\mathrm{W} / \mathrm{H} \\
(\%)\end{array}$ & $\begin{array}{l}\text { anxials } \\
\text { pen bod }\end{array}$ & $\underset{\text { plaits }}{\text { columellar }}$ \\
\hline C 134689 & 6.80 & 4.75 & 2.90 & 70.0 & 42.6 & 10 & 3 \\
\hline
\end{tabular}

Diagnosis.-Shell minute, solid and biconically fusiform. Protoconch paucispiral, depressed with smooth volutions. Teleoconch-whorls medially angulated. Sculpture of bold axials and distinct spirals below peripheral angulation. Axials and spirals on the subsutural sulcus much weaker. Aperture large and wide with subparallel lips. Parietal callus thick. Canal widely open, short and terminally truncated. Columellar lip with four plaints. Labrum sharp and thin at the margin and thickened inside. Anal sinus moderately shallow occupying shoulder slope.

Descriptive remarks. - The specimen is a collection on a beach and its apical part is slightly abraded. Boundary between the protoconch and teleoconch is very sharp. Axial ribs are ten on the second whorl. While they are raised and granular on the angulation and weaker above the angulation but reach to the upper suture on that whorl, they become weak on the shoulder slope on the later whorls. Spiral lirae are two on the second whorl and then other lirae appear one by one from the lower suture (adapical development, Shuto, 1969, p. 47). Spirals on the shoulder slope are 11 to 12 (on the penultimate whorl), almost equally sized and remarkably weaker than those on the lateral surface. Growthlines are distinct on the shoulder sulcus. Axials on the body whorl reach to the upper part of the snout, where they form granules at intersections with spirals. Inner and outer lips of the aperture are subparallel. Upper three of four plaits are somewhat stronger than the lowest one.

Comparison.-Generic position of the present borsonine taxon is not necessarily certain. It is the closest to Vexithara FInLAY, 1926, an Oligocene genus 


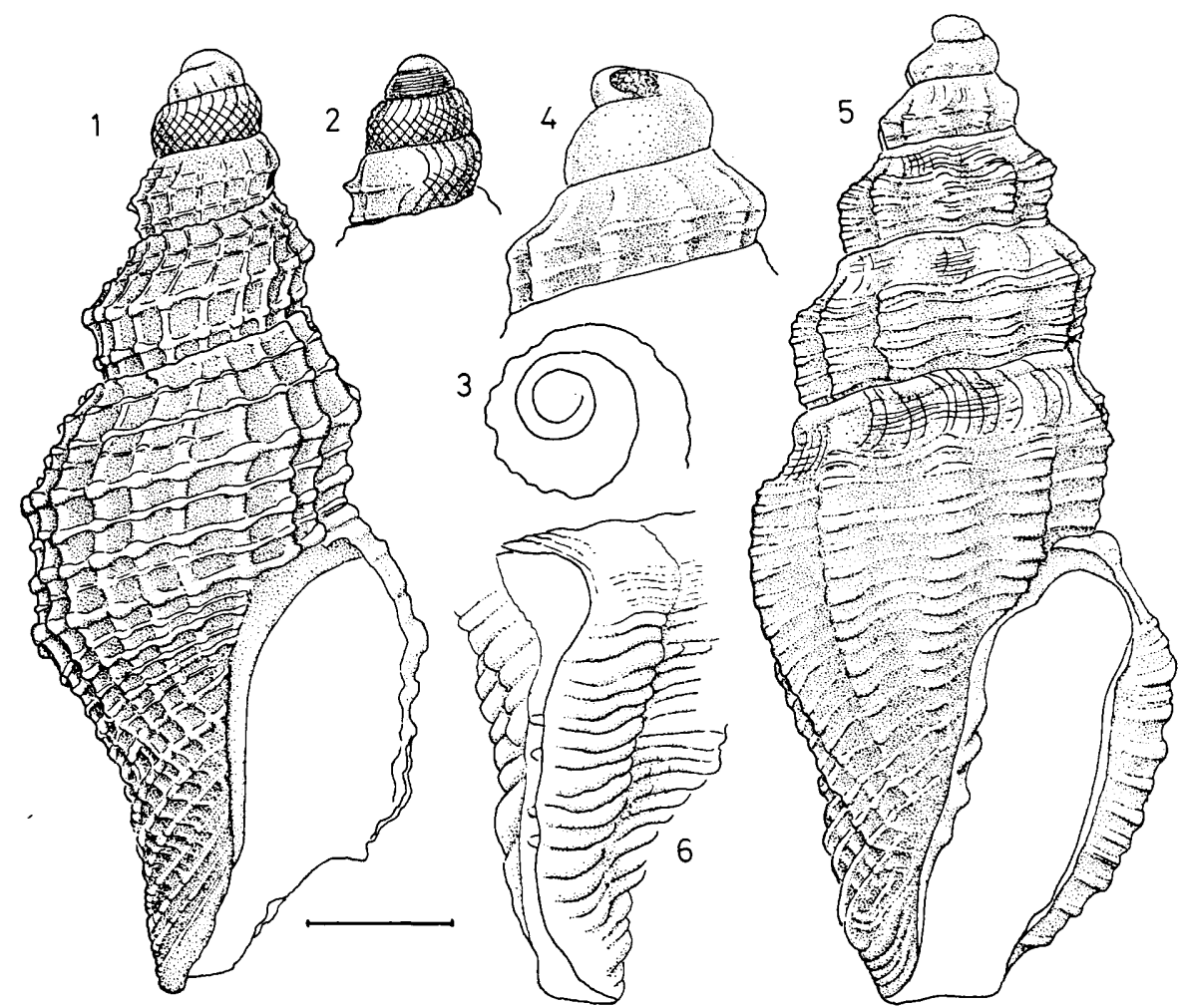

Fig. 5. Australian turrids 1-3. Austrodaphnella torresensis sp. nov. holotype, C 134682a, front view (1) and apical view of coiling of suture (3). paratype, C 134682b, protoconch (2). 4-6. Vexithara brevicanalis sp. nov. holotype, C 134689, front view (5), protoconch (4) and anal sinus (6).

Sacle bar $1 \mathrm{~mm}$ for 5 and $6 ; 0.5 \mathrm{~mm}$ for $1,2,3$ and 4 .

of New Zealand and reasonably included in it. However, the former shows somewhat different features from the latter in having shorter and wider base, weaker peripheral angulation particularly on the body whorl and more numerous columellar plaits. It may represent a new subgenus of Vexithara, but I prefer to include it in that genus provisionally because the present specimen is not satisfactorily preserved.

Vexithara is a very small group of the turrids and the present taxon is characteristic by its numerous columellar plaits and wide and short canal among the known species of the genus.

\section{Subfamily Clavinae \\ genus Horaiclavus OYAMA, 1954}

Type-species: Mangilia splendida A. AdAMs, 1867 (o. d.)

subgenus Anguloclavus subgen. nov.

Type-species: Mangilia multicostata SCHEPMAN

Diagnosis.-Shell fusiform and moderate in size. Protoconch smooth, globose consisting of about one and two-thirds volutions. Teleoconch-whorls sharply 
angulate at lower two-fifths of whorl-height. Spiral lira on peripheral angulation becoming weak through growth stages. Axials very thin, vertical, slightly opisthocyrtly curved, granular on the peripheral angulation and weakened above and below the angulation. No spirals except on snout and basal slope in adult stage. Spirals on snout smooth and distinct, and those on lower part of basal slope faint. Aperture pyriform, angulate postriorly, varicose outside labrum and callous on inner lip. Parietal callus distinct. Canal short, widely open and terminally truncated. No vestige of anal sinus.

Comparison.-The present taxon is provided with sharp peripheral angulation, otherwise it quite conforms with Horaiclavus OYAMA, 1954. Morphological difference is so conspicuous that their separation at generic level seems reasonable at the first glance. However, the present taxon has the roundly convex first whorl and the peripheral angulation appears on the second. The fact suggests a close taxonomic relation between Horaiclavus and Anguloclavus.

It seems questionable whether Horaiclavus and Anguloclavus really belong to Turridae or not because they have no vestige of an anal sinus as Powell mentioned (1966, p. 142). Radula of $H$. splendidus is, however, true toxoglossate according to Kuroda, HABE and OYAMA (1971, p. 327) and Anguloclavus is provisionally placed in Turridae.

\section{Horailavus (Anguloclavus) multicostatus (SCHEPMEN) \\ Pl. 1, Figs. 9 and 10, Text-fig. 6}

1913. Mangilia multicostata Schepmen, Siboga Expeditie Monogr. No. 49, p. 432, pl. 38, f. 12.

Material.-C 134663 from BMR Stn. p 691 1154, ca 150 miles north of Cobourg Peninsula $\left(9^{\circ} 17.5^{\prime} \mathrm{S}, 132^{\circ} 20^{\prime} \mathrm{E}\right)$, Northern Territory. P. H. ColmaN coll., Nov. 10, 1969.

\begin{tabular}{|c|c|c|c|c|c|c|c|}
\hline specimen & $\underset{(\mathrm{mm})}{\mathrm{H}}$ & $\underset{(\mathrm{mm})}{\mathrm{Bd}}$ & $\underset{(\mathrm{mm})}{\mathrm{W}}$ & $\begin{array}{c}\mathrm{Bd} / \mathrm{H} \\
(\%)\end{array}$ & $\begin{array}{l}\mathrm{W} / \mathrm{H} \\
(\%)\end{array}$ & $\begin{array}{l}\text { protoconch } \\
\text { vols. } \mathrm{D}(\mathrm{mm})\end{array}$ & $\begin{array}{l}\text { teleoconch } \\
\text { whorls }\end{array}$ \\
\hline C 134663 & 16.35 & 8.05 & 6.15 & 49.2 & 37.6 & 0.7 & 9.5 \\
\hline
\end{tabular}

Descriptive remarks and comparison.-Globose and smooth protoconch is large, measured $0.7 \mathrm{~mm}$ in diameter. Boundary between the protoconch and teleoconch is not defined by a sharp ridge or groove, but suggested by appearance of axial lirae of teleoconch. Axial lirae are weak and opisthocline and opisthocyrtly curved at first then gradually become vertical. Peripheral angulation appears at about a half turn of the first whorl and becomes sharp on the later part of the same whorl. Axials are granular at the intersections with the peripheral angulation and they are laterally extended and continue with one another forming a superimposed lira on the angulation on the third whorl. Spiral lira on the angulation is again weakened between the axials on the sixth and later whorls. All the sculpture except for spirals on the anterior part becomes weak on the later whorls.

The present specimen is quite identical to SchepmaN's specimen except for number of the axials. The former has 13 axials instead of 16 of the latter. Its 
morphological relationship to Horaiclavus splendidus (A. ADAMS) was stated above.

\author{
Subfamily Mangeliinae \\ genus Graciliclava nov.
}

Type-species: Graciliclava mackayensis gen. et sp. nov.

Diagnosis.-Shell small and claviform. Protoconch with about 2.5 volutions. The first volution smooth and remainder ones medially carinate. Teleoconch with about six whorls. Whorls with slightly curved and fold-like axial ribs and dense and minute spiral lines. Axials from suture to suture on spire and extending to basal contraction on body whorl. The uppermost one of spiral lirae on snout subgranular. Aperture rhomboid with short, wide and weakly notched canal. Labrum thin and simple at very margin and strengthened by a varix behind. Anal sinus very shallow reversed L-shape below sutre. Stromboid notch narrow and deep. Parietal callus thick.

Comparison.-The present taxon is characterized by medially carinate protoconch volutions and very shallow anal sinus and must be included in Mangeliinae, although it shows a claviform profile.

Teleoconch of the present taxon looks like that of Inodrillia BARTSCH, 1943, (type-species: Pleurotoma (Drillia) mucleata DALL (o. d.)), but is quite differs in protoconch.

The present taxon is similar to Anacitharoida SHUT0, 1965, (type-species: Anacithara (Anacitharoida) kurodae SHuTo (o. d.)) in the protoconch and teleoconch. They share common features that the protoconch is carinate, the teleoconch has fold-like axials from suture to suture and minute and dense spiral lines and that the anal sinus is very shallow below suture. However, the present taxon shows more definite basal contraction and very characteristic stromboid notch on labrum.

It is also distinguished from Apitua delicatula LASERON, the type-species of Apitua LASERON, 1954, in having more volutions on the protoconch, much weaker and more numerous spiral sculpture on the teleoconch, decidedly shallower anal sinus and distinct stromboid notch.

Graciliclava mackayensis gen. et sp. nov.

Pl. 1, Figs. 2-5, Text-fig. 6

Material.-holotype: C 134685 from HMAS "Kimbla" Stn. 8, east of Mackay ( $\left.20^{\circ} 52^{\prime} \mathrm{S}, 149^{\circ} 29^{\prime} \mathrm{E}\right)$, Queensland, depth $35 \mathrm{~m}$. P. H. ColmaN and F. Rowe coll., Nov. 19, 1977. Paratype, C 134680 from BMR Stn. 1254, northeast of Rockhampton $\left(22^{\circ} 40^{\prime} \mathrm{S}, 151^{\circ} 16^{\prime} \mathrm{E}\right)$, Queensland, depth 58m. Sept. 20, 1970. P. H. COLMAN and F. ROWE coll.

\begin{tabular}{|c|c|c|c|c|c|c|c|c|}
\hline specimen & $\underset{(\mathrm{mm})}{\mathrm{H}}$ & $\underset{(\mathrm{mm})}{\mathrm{Bd}}$ & $\underset{(\mathrm{mm})}{\mathrm{W}}$ & $\underset{(\%)}{\mathrm{Bd} / \mathrm{H}}$ & $\begin{array}{l}\mathrm{W} / \mathrm{H} \\
(\%)\end{array}$ & $\begin{array}{l}\text { prc } \\
\text { vols. }\end{array}$ & $\begin{array}{l}\text { conch } \\
\mathrm{D}(\mathrm{mm})\end{array}$ & $\begin{array}{l}\text { teleoconch } \\
\text { whorls }\end{array}$ \\
\hline 1346 & 7.10 & 3.95 & 3.05 & 55.6 & 43.0 & 2.5 & 0.65 & 5.5 \\
\hline & 7.95 & 4.30 & 3.55 & 54.1 & 44.7 & 2.5 & 0.60 & 6.1 \\
\hline
\end{tabular}


Diagnosis.-The same as the generic diagnosis.

Descriptive remarks.-Spiral sculpture appears as six or seven distinct threads on the first whorl, then the secondary and tertiary lines are intercalated as shell grows and the primaries and secondaries become as weak as the tertiaries.

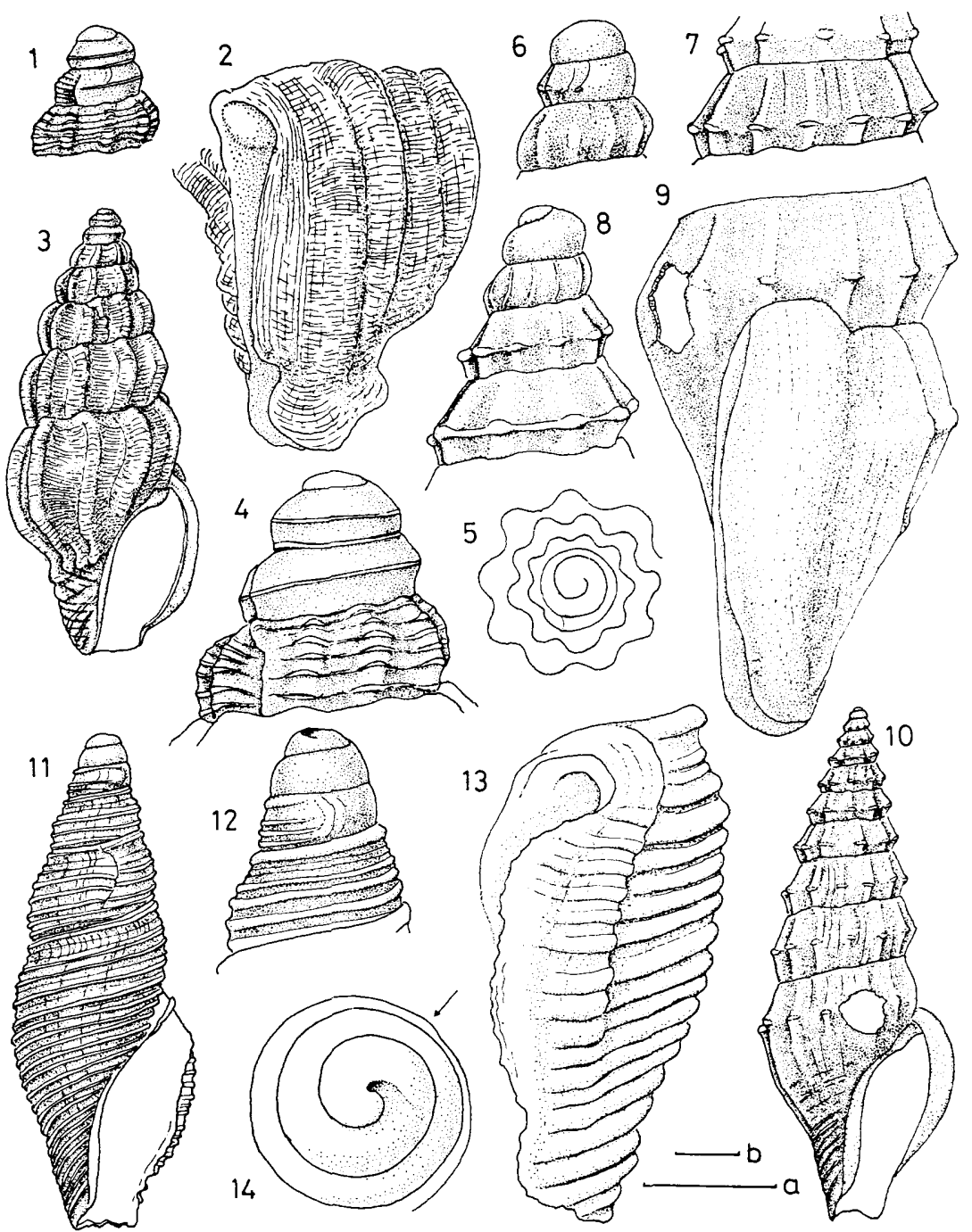

Fig. 6. Australian turrids 1-5. Graciliclava mackayensis gen. et sp. nov. holotype, C 134685, anal sinus (2), front view (3), protoconch (4) and apical view of coiling of suture (5). paratype, C 134680. protoconch (1). 6-10. Horaiclavus (Anguloclavus) multicostatus (SCHEPMAN), subgen. nov., C 134663, protoconch (6), seventh whorl (7), apical part (8), side view of the body whorl (9) and front view (10). 11-14. Austropusilla (Metaclathurella) crokerensis sugen. et sp. nov. holotype, C 134692, front view (11), apical part (12), anal sinus (13) and apical view of coiling of suture (14).

Scale bar a $1 \mathrm{~mm}$ for $1,2,5,6,8,12$ and $13 ; 0.5 \mathrm{~mm}$ for 4,12 and 14 . Scale bar b $1 \mathrm{~mm}$ for $3,7,9$ and $11 ; 2 \mathrm{~mm}$ for 10 . 
Axial folds are as wide as the interspaces and nine and 10 respectively on the first and second whorl.

Comparison.-Graciliclava mackayensis is closely similar to "Haedropleura" laeta THIELE (1925, p. 307, pl. 25, f. 24) from Tuti, south India in the general form, but is distinguished from the latter in having nodulous spiral liare on the upper part of the snout and more curved axials than the latter.

Genus Euryentmena WoodrING, 1928

type-species: Euryentmena cigclis Woodring, (o. d.)

Euryentmena australiana sp. nov.

Text-figs. 1 and 3

Material.-holotype: C 134678 from HMAS “Gascoyne” Stn. G2/55-57/62, east of Sydney, New South Wales. Depth 75-150 m. CSIRO coll., July 18, 1962.

Measurements.-

\begin{tabular}{|c|c|c|c|c|c|c|c|}
\hline specimen & $\underset{(\mathrm{mm})}{\mathrm{H}}$ & $\underset{(\mathrm{mm})}{\mathrm{Bd}}$ & $\underset{(\mathrm{mm})}{\mathrm{W}}$ & $\begin{array}{c}\mathrm{Bd} / \mathrm{H} \\
(\%)\end{array}$ & $\underset{(\%)}{\mathrm{W} / \mathrm{H}}$ & $\begin{array}{c}\text { protoconch } \\
\text { vols. } D(\mathrm{~mm})\end{array}$ & $\begin{array}{l}\text { teleoconch } \\
\text { whorls }\end{array}$ \\
\hline C 134678 & 4.65 & 3.30 & 2.40 & 71.0 & 51.6 & $2.0 \quad 0.75$ & 3.2 \\
\hline
\end{tabular}

Diagnosis.-Shell minute, biconically fusiform. Protoconch paucispiral, large, globose and superficially smooth, but microgranular under microscope. Boundary defined by a sharp ridge. Teleoconch-whorls on spire convex, biangulate, and separated from one another by undulating impressed sutures. Body whorl large occupying more than 70 percent of whole height. Base remarkably contracted. Sculpture of coarse cancellation of axials and spirals. Axials from suture to suture, sharply elevated and slightly sigmoidally curved. Spirals strong and cross over axials forming granules at crossings. Aperture pyriform with widely open, terminally truncated canal. Anal sinus very shallow occupying whole shoulder slope.

Descriptive remarks.-Axials are reversed sigmoid and to merge to the upper suture with prosoclinal upper part. Prosoclinal part is more inclined on earlier whorls. Axials are strong and raised below the upper angulation and become thin but equally erect above it. Primary spirals are three on the first whorl, of which the uppermost one is suggested by a spirally oriented granules on axials and the lowest one is half covered by the succeeding whorl. Secondary spiral appears first on the lowest interspace, then does successively on the upper interspaces. One on the shoulder slope is very weak between the axials but peculiarly bulged on the axials. On the body whorl axials become gradually weak on the basal slope and almost disappear at the contraction between basal slope and snout, but their continuation on the long and vertical snout is suggested by raws of microgranules on spiral lirae. Spirals on the basal slope are weaker than those on lateral surface and snout. Callus of the inner lip is remarkably wide but not thick. Details of labrum is not known because of partial fracture. Probably no varix.

Comparison.-The present species is closely similar to Euryentmena cigclis WOODRING $(1928$, p. 196, pl. 8, f. 13), the type-species of the genus, but is clearly 
distinguished from the latter in that its axials are not weaken remarkably on the shoulder slope and provided with spirally oriented granules and its canal is not terminally notched. No other comparable species.

genus Antiguraleus Powell, 1942

type-species: Antiguraleus otagoensis PoWELL, o. d.

Antiguraleus stellatomoides sp. nov.

Pl. 2, Figs. 8 and 9, Text-fig. 3

Material.-holotype: C 134686a and paratypes C 134686b and c. All from HMAS “Kimbla" Stn. 20, 16.8 miles northeast of North Reef $\left(23^{\circ} 08.4^{\prime} \mathrm{S}, 152^{\circ}\right.$ 12.3' E), Queensland. Depth 115 m. W. F. Ponder, I. LoCH and P. TERrill coll., Dec. 14, 1977.

\begin{tabular}{|c|c|c|c|c|c|c|c|c|}
\hline pecimen & $\underset{(\mathrm{mm})}{\mathbf{H}}$ & $\underset{(\mathrm{mm})}{\mathrm{Bd}}$ & $\underset{(\mathrm{mm})}{W}$ & $\underset{(\%)}{\mathrm{Bd} / \mathrm{H}}$ & $\begin{array}{l}\mathrm{W} / \mathrm{H} \\
(\%)\end{array}$ & $\begin{array}{l}\text { prot } \\
\text { vols. }\end{array}$ & $\begin{array}{l}\text { conch } \\
\mathrm{D}(\mathrm{mm})\end{array}$ & $\begin{array}{l}\text { teleoconch } \\
\text { whorls }\end{array}$ \\
\hline & 9.35 & 6.30 & 4.60 & 67.4 & 49.2 & 1.7 & 0.90 & 4.2 \\
\hline 12 & 8.90 & 6.10 & 4.25 & 68.5 & $47 \cdot 8$ & 1.7 & 0.90 & 4.0 \\
\hline
\end{tabular}

Diagnosis.-Shell small, biconically fusiform and solidly built. Protoconch paucispiral, globose and smooth. Teleoconch whorls medially angulated and separated from one another by wavy suture. Spirals distinct only on snout and peripheral angulation. Axials thin and slightly sigmoid. Aperture rhomboid with differentiated, widely open and terminally truncated canal. Labrum sharp and thin at the margin but strengthened by a distinct varix behind. Anal sinus shallow below the suture.

Descriptive remarks.-Protoconch consists of one and two-thirds smooth volutions of which the first is slightly oblique. Boundary between the protoconch and the teleoconch is an opisthocyrtly curved sharp line. Teleoconch-whorls are convex and subangulated at periphery. The first whorl is sculptured with slightly sigmoidal thin axials and a weak median thread, which is somewhat stronger on axials than on interspaces between axials. Axials reach both to the upper and lower sutures on the spire and disappear on the basal slope of the body whorl. Body whorl is large occupying about two-thirds of whole height of the shell. Basal contraction is distinct. Spirals on snout are regularly spaced and much stronger than those on the peripheral part. Growthlines are distinct and parallel to the axial ribs. Aperture is elongate pyriform with differentiated and terminally truncated canal. Labrum is thin, sharp at the margin, smooth inside and strengthened by a varix outside. Inner lip is covered with distinct callus with sharp edge.

Material consists of three specimens. Specimen $b$ is slightly different from others in having two to three spirals at and near the peripheral angulation, otherwise it quite conforms with others.

Comparison.-The present species conforms with the general feature of Antiguraleus Powell, 1942, except for spiral sculpture and labrum varix. Spirals are developed only on snout and peripheral part on the present species, while 
they are distinct and regularly spaced on whole surface of typical species of Antiguraleus. The present species is similar to Stellatoma BARTSCH and REHDER, 1939, in its protoconch, shell-profile, sculpture, labrum varix and callus on inner lip, but it is clearly distinguished from the latter in having differentiated, rather long canal and being devoid of blunt denticulation at upper part of labrum. In short the present species shows an intermediate feature between Antiguraleus and Stellatoma. The present author is, however, inclined to include the present species in Antiguraleus evaluating the characteristics of aperture.

It is closely similar to Mangilia woodwardiae MeLviLL from Persian Gulf (1917, p. 179, pl. 10, f. 9), but the former has definitely stronger spirals on the snout and shorter spire than the latter. Pleurotoma angicostata REEvE (1844, pl. $36, \mathrm{f} .327$ ) is an another allied species to the present taxon, but the former has only six axial ribs for one whorl and is devoid of spirals on the snout.

It is also similar to Mangelia misera THIELE (1925, p. 198, pl. 28, f. 1) from Agulhasbank, but is readily distinguished from the latter, which seems to be a juvenile specimen and is characterized by less sigmoid axials, weaker basal contraction and spiral-free ornamentation.

genus Austropusilla LASERON, 1954

type-species: Mangelia hilum HEDLEY, o. d.

subgenus Metaclathurella subgen. nov.

type-species: Austropusilla (Metaclathurella) crokerensis subgen. et sp. nov.

Diagnosis.- Shell small, solid and fusiform with high spire and tapered base. Protoconch polygyrate and smooth. Apex oblique and depressed. Teleoconchwhorls roundly convex with obscure subsutural band and sculptured with spiral lirae. Suture impressed. Aperture long pyriform with short and wide canal and with subtubular anal sinus narrowed by a thick parietal callus pad. Columellar lip vertical and simple. Labrum thin at the margin and strengthened behind by strong varix. Growthlines distinct showing moderately shallow and open sinus immediately below suture.

Comparison.-Many species of Euclathurella WooDRING, 1928, show a tendency of weakening axial ribs through growth stages. The present subgenus is similar to the adult facies of above mentioned one, but is readily distinguished from the latter in having quite smooth polygyrate protoconch with apical depression and much stronger spiral lirae which start at the very beginning of the teleoconch.

It is closely similar to Filodrillia HEDLEY, 1922, particularly to a group of axial-free species, but differs from those species in having above mentioned characteristic protoconch and much stronger spiral cords. The present taxon is the most closely related to Austropusilla LASERON, 1954, with important common features of spirally sculptured fusiform shell with apically depressed protoconch. The former is separated from the latter in having stouter spirals and defined shoulder sulcas. The present taxon must be regarded as a subgenus of Austropusilla. 
Austropusilla (Metaclathurella) crokerensis sugen. et sp. nov. Pl. 2, Figs. 1 and 2, Text-fig. 6

Material.-holotype: C 134692 from Arafra Sea approximately 45 miles north of Croker Island $\left(10^{\circ} 17^{\prime} \mathrm{S}, 132^{\circ} 38^{\prime} \mathrm{E}\right)$, Northern Territory. Depth, $65 \mathrm{~m}$. P. H. Colman coll. Nov. 9, 1969. Specimen is slightly broken at the edge of canal.

\begin{tabular}{|c|c|c|c|c|c|c|c|}
\hline specimen & $\underset{(\mathrm{mm})}{\mathbf{H}}$ & $\underset{(\mathrm{mm})}{\mathrm{Bd}}$ & $\underset{(\mathrm{mm})}{\mathrm{W}}$ & $\begin{array}{c}\mathrm{Bd} / \mathrm{H} \\
(\%)\end{array}$ & $\begin{array}{l}\mathrm{W} / \mathrm{H} \\
(\%)\end{array}$ & $\begin{array}{c}\text { protoconch } \\
\text { vols. } \mathrm{D}(\mathrm{mm})\end{array}$ & $\begin{array}{l}\text { teleoconch } \\
\text { whorls }\end{array}$ \\
\hline C 134692 & 7.90 & 4.85 & 2.90 & 61.4 & 36.7 & $3.1 \quad 0.95$ & 3.9 \\
\hline
\end{tabular}

Diagnosis.-The same as the generic diagnosis.

Description.-Protoconch consists of 1.2 prehatching volutions (protoconch I) and 1.8 posthatching ones (protoconch II). Protoconch I has a clear depression. The first teleoconch-whorl has four spiral lirae, of which the subsutural one is stronger than the others and separated from the next below one by a moderately wide shoulder band on which growthlines are distinct. On the second whorl somewhat weaker threads appear on this shoulder band. Spirals consist of 22 primary lirae and several minute secondaries on the body whorl. Aperture is long elliptical with undifferentiated canal. Anal sinus is subtubular narrowed by a ridged parietal callus.

Comparison.-The present species is somewhat similar to Filodrillia delecta HEDLEY (1922, p. 221, f. 2) from New South Wales and South Australia, but is readily distinguished from the latter in having apically depressed protoconch and stouter and more numerous spiral cords. Besides, the present species has a defined shoulder sulcus between the prominent subsutural and peripheral cords.

Austropusilla hilum (HEDLEY) (1908, p. 471, pl. 9, f. 17) from New South Wales and Victoria shows a similar morphological facies to the present species, but its spirals are much weaker and anal sinus suggested by growthline is shallower than in the latter.

\author{
Subfamily Daphnellinae \\ genus Philbertia Monterosato, 1884 \\ type-species: Pleurotoma philberti Michaud, 1830, tautonomy \\ subgenus Glyphostomoides subgen. nov. \\ type-species: Philbertia (Glyphostomoides) queenslandica subgen. \\ et sp. nov.
}

Diagnosis.-Shell minute, fusiform and solid. Protoconch polygyrate with diagonal cancellation. Teleconch-whorls peripherally angulated and sculptured with prominent axial plicae overridden by distinct spirals. Wrinkled minute and dense growthlines on interspaces between spirals. Aperture elongate pyriform with defined and moderately long canal. Inner lip simple with thin and narrow callus. Labrum thin at the margin, but strongly variced behind and denticulate inside. Anal sinus narrow, moderately deep and reversed L-shape below suture. Subsutural anal fasciole with raised growth threads and weak spiral lines. 
Comparison.-The present taxon shows superficial resemblance to Glyphostoma GABB, 1872, with diagnostic features, but has a typical daphnelloid protoconch. It is distinguished from Philbertia Monterosato, 1884, in having three pairs of denticles inside the labrum instead of regularly spaced spiral lirae of Philbertia, besides, the former is provided with a prominent labrum varix and subsutural anal fasciole with raised growth threads.

It is also distinguished from Kermia OLIVER, 1915, in having high conical spire instead of cylindrical one of Kermia, distinct subsutural anal fasciole, longer canal and more prominent axial plicae.

Philbertia (Glyphostomoides) queenslandica subgen. et sp. nov. PI. 1, Fig. 6, Text-fig. 2

Material.-holotype: C 134681 from BMR Stn. 1253, northeast of Rockhampton $\left(22^{\circ} 42^{\prime} \mathrm{S}, 151^{\circ} 37^{\prime} \mathrm{E}\right)$, Queensland. Depth, $68 \mathrm{~m}$. Sept. 20, 1970. The specimen is slightly eroded at the very apex and broken at the end of canal.

\begin{tabular}{lccccccc}
\multicolumn{2}{c}{ Measurements.- } & & & & \\
specimen & $\mathrm{H}$ & $\underset{\mathrm{Bd}}{\mathrm{Bm}})$ & $(\mathrm{mm})$ & $\underset{(\mathrm{mm})}{\mathrm{W}}$ & $\begin{array}{c}\mathrm{Bd} / \mathrm{H} \\
(\%)\end{array}$ & $\begin{array}{c}\mathrm{W} / \mathrm{H} \\
(\%)\end{array}$ & \multicolumn{2}{c}{$\begin{array}{c}\text { whorls } \\
\text { proto }\end{array}$} \\
C 134681 & 6.40 & 3.25 & 2.40 & 50.8 & 37.5 & $2.5+$ & 6.7
\end{tabular}

Diagnosis.-The same as the subgeneric diagnosis.

Remarks and comparison.-Axial plicae reach to the upper portion of snout. Spirals on the body whorls consist of the primary lirae, secondary threads and tertiary lines except on the snout, on which all the spirals are of primary order.

The present species shows a resembling adult feature to Etrema nassoides (REEVE) (1845, pl. 29, f. 259), but differs from the latter in the protoconch and in the subsutural anal fasciole. There is no comparable daphnelid species ever reported.

genus Vepridaphne gen. nov.

type-speciess Daphnella cestrum HEDLEY, 1922

Diagnosis.-Shell minute and fusiform with tall spire and long and vertical snout. Base distinctly contracted. Protoconch polygyrate (three volutions); tip spirally striated, following one volution with distinct and regular spiral striae and irregular axial ones, last one and a third volutions provided with diagonal cancellation on the lower half and axial threads on upper half. Teleoconch sculpture of prominent and raised axial folds overridden by coarse spirals. Intersections granular. Curved axial threads distinct on the anal band on which axial folds abruptly disappear. Aperture pyriform with moderately long, straight and open canal. Terminal of canal obliquely truncated. Anal sinus moderately shallow reversed L-shape just below suture.

Comparison.-The present taxon is quite similar to Veprecula Melvill, 1917, in the characteristic of the teleconch, but quite differs from the latter in the protoconch. The protoconch of the former is sculptured by spiral striation, reticulation and diagonal cancellation instead of axial riblets of the latter. 


\section{Vepridaphne cestrum (HEDLEY)}

Pl. 1, Fig. 1, Text-figs. 1 and 7

1922. Daphnella cestrum Hedley, Rec. Austral. Mus. Vol. 13, No. 6, p. 327, pl. 53, f. 160 .

Material.-C 134687 from approximately 100 miles northwest of Broome (16 ${ }^{\circ}$ $\left.58^{\prime} \mathrm{S}, 120^{\circ} 47^{\prime} \mathrm{E}\right)$. Depth, $194 \mathrm{~m}$. C 134662 and C 134693 from Arafra Sea, approximately 45 miles north of Croker Island $\left(10^{\circ} 17^{\prime} \mathrm{S}, 132^{\circ} 38^{\prime} \mathrm{E}\right)$, Northern Territory. Depth $65 \mathrm{~m}$. Nov. 9, 1969. C 134691 from $160 \mathrm{~km}$ north of Goulburn Island $\left(10^{\circ} 08^{\prime} \mathrm{S}, 133^{\circ} 05^{\prime} \mathrm{E}\right)$, Northern Territory. Depth, $73 \mathrm{~m}$. P. H. ColmaN coll., Nov. 1, 1969. C 134683 from HMAS “Kimbla" Stn. 16, east of Sarina (21 27.5' S, $150^{\circ} 08^{\prime} \mathrm{E}$ ), Queensland. Depth, $42 \mathrm{~m}$. W. F. Ponder, I. Loch and P. TerRIL coll. C. 134693 locality unknown.

\begin{tabular}{lccccccc}
\multicolumn{2}{c}{ Measurements.- } & & & & & \\
specimen & $\begin{array}{c}\mathrm{H} \\
\mathrm{mm})\end{array}$ & $\begin{array}{c}\mathrm{Bd} \\
(\mathrm{mm})\end{array}$ & $\begin{array}{c}\mathrm{W} \\
(\mathrm{mm})\end{array}$ & $\begin{array}{c}\mathrm{Bd} / \mathrm{H} \\
(\%)\end{array}$ & $\begin{array}{c}\mathrm{W} / \mathrm{H} \\
(\%)\end{array}$ & $\begin{array}{c}\text { protoconch } \\
\text { vols. }\end{array}$ & $\mathrm{D}(\mathrm{mm})$ \\
C 134691 & 3.90 & 2.51 & 1.45 & 55.4 & 37.6 & 3.1 & 0.42 \\
C 134687 & 5.20 & 3.00 & 2.05 & 57.6 & 39.6 & 3.2 & 0.42 \\
C 134662 & 5.05 & 2.90 & 1.95 & 57.2 & 30.2 & 3.0 & 0.45 \\
C 134683 & 11.05 & 6.35 & - & 57.5 & - & 3.0 & 0.44
\end{tabular}

Remarks.-Protoconch consists of three to three and a quater volutions. Its sculptural pattern is regular; spirally striated part is followed by a reticulated part and then by diagonally cancellated part. Boundary between the protoconch and teleoconch is sharp indicated by abrupt replacement of diagonal cancellation by two prominent spiral cords. Primary spiral cords are three and a secondary thread on shoulder slope appears on the third to fourth whorl and other secondaries are intercalated on the fourth and later whorls. Seventh and later whorls have even the tertiary threads. Area between major spirals are covered with minute granules, which are formed by reticulation of minute and dense axial and spiral lines. Labrum is lirated inside corresponding with major spiral cords outside. Anal sinus is moderately deep, reversed L-shaped jujst below the suture.

Comparison.-The largest specimen (C 134683) quite conforms with the figured type of the original author (HEDLEY, 1922, pl. 53, f. 160).

Clathurina netrodes Melvill (1917, p. 187, pl. 10, f. 17) shows a similar facies of both protoconch and teleoconch to the present species, but the latter differs from the former in having shorter spire, more distinctly contracted base and more prominent axials separated by wider interspaces.

Pleurotoma gracilispira SмIтн (1979, p. 196, pl. 19, f. 25) from the Japanese water is also a close ally to the present species, but is larger, slenderer and is sculptured with more numerous axials than the latter. Besides, the former is provided with microspiral lines instead of microgemmules of the latter.

genus Tritonoturris DALL, 1924

type-species: Clathurella robillardi "BARClaY, 1869" = H. ADAMs, 1869, o. d.

Tritonoturris buccinoides sp. nov.

PI. 2, Figs. 12 and 13, Text-fig. 4 


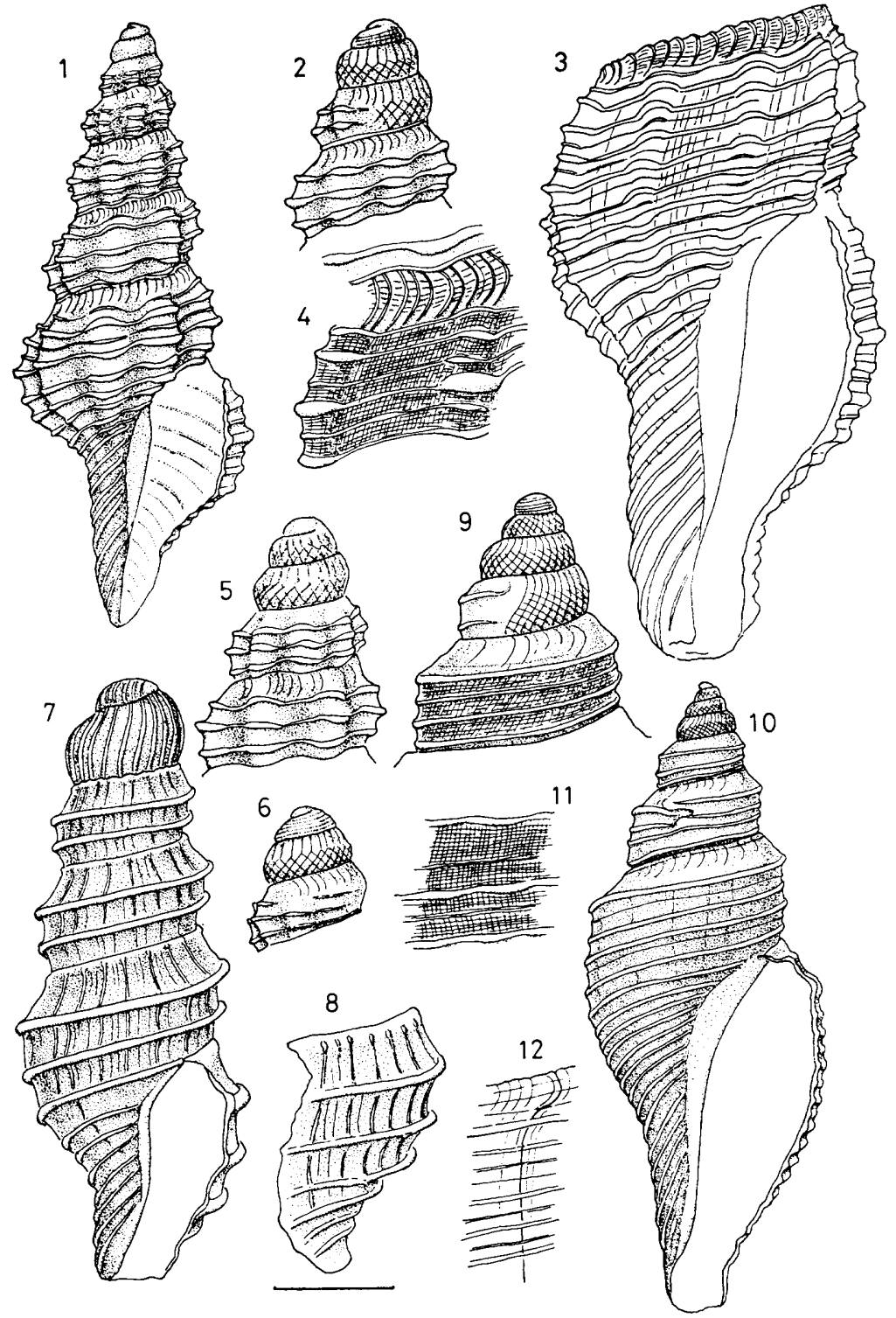

Fig. 7. Australian turrids 1-6. Vepridaphne cestrum (HEDLEY), gen. nov. C 134687, front view (1) and apical part (2); C 134691, sculptural pattern on the body whorl (4) and protoconch (6); C 134683, body whorl (3) and apical part (5). 7-8. Pseudexomilus bicarinatus sp. nov. holotype, C 134679, front view (7) and anal sinus (8). 9-12. Pagodidaphne colmani gen. et sp. nov. holotype, C 134667, apical part (9), frontal view (10), sculptural pattern on the penultimate whrol (11) and anal sinus suggested by growthlines on the body whorl (12).

Scale bar $1 \mathrm{~mm}$ for $1,3,10$ and $12 ; 0.5 \mathrm{~mm}$ for $2,4,5,6,7,8,9$ and 11. 
Material.-holotype: C 134673a from Bottle and Glass Rocks, Sydney Harbour, New South Wales. Depth 3.5-7.5 m. J. VooRwinde coll. Paratype, C 134673b came from the same locality as the holotype.

\begin{tabular}{|c|c|c|c|c|c|c|c|}
\hline specimen & $\underset{(\mathrm{mm})}{\mathrm{H}}$ & $\underset{(\mathrm{mm})}{\mathrm{Bd}}$ & $\underset{(\mathrm{mm})}{\mathrm{W}}$ & $\begin{array}{c}\mathrm{Bd} / \mathrm{H} \\
(\%)\end{array}$ & $\underset{(\%)}{\mathrm{W} / \mathrm{H}}$ & \multicolumn{2}{|c|}{$\begin{array}{l}\text { whorls } \\
\text { proto. teleo. }\end{array}$} \\
\hline C $134673 a$ & 6.95 & 4.05 & 3.35 & 58.3 & 48.2 & $3+$ & 4.8 \\
\hline C $134673 b$ & 6.50 & 4.00 & 3.25 & 61.5 & 50.0 & 3.6 & 4.5 \\
\hline
\end{tabular}

Diagnosis.-Shell small and bucciniform. Protoconch polygyrate, diagonally cancellated on later volutions and superimposed with three spiral threads on the last part. Teleoconch-whorls angulated in the early stage and rounded later, sculptured with prominent axial folds overridden by spiral cords. Axials separated by wider and flat interspaces, reaching to the sharp basal contraction. Growthlines distinct, sigmoid and oblique to the axials. Snout straight and vertical. Sutures wavy. Anal sinus moderately deep, reversed L-shape just below suture. Aperture rhomboid with defined, widely open and terminally truncated canal.

Description-Protoconch is conical consisting of more than three volutions, of which the last two, at least, are diagonally cancellated by opisthocyrt opisthocline and prosocline fine lines. The prosocline lines are restricted on the lower two-thirds. Three spiral threads override the cancellation on the last part and then protoconch sculpture is gradually replaced by crude teleoconch sculpture. Spiral threads of protoconch develop into cords of teleoconch and the median cord is located on the peripheral angulation. Anal band is at first free from spirals and provided with short, curved growth threads, then it loses growth threads and is encircled with secondary threads later. Secondaries, intercalated between the primaries on the lateral surface, become as prominent as the primaries on the body whorl. Axials disappear on the anal band in the early stage, then gradually stretch to the upper suture in growth. On the body whorl they reach both to the upper suture and basal contraction. Axials are separated by wider interspaces with flat bottom and the boundary between axial folds and interspaces is sharply reflected. Vertical snout is provided with regular spiral lirae. Aperture is rhomoid with defined canal, which is widely open and terminally truncated. Anal sinus is moderately deep reversed L-shape just below suture. Coloration of $\mathrm{C} 134673 \mathrm{a}$ is brown on the axials otherwise white, while C $134673 \mathrm{~b}$ is brown. Two specimens quite conform to each other except for a minor difference that the latter has more prominent and raised axials than the former.

Comparison.-Protoconch of the present species is identical to that of Pleurotomella VERRILL, 1873, but the former is provided with decidedly shallower anal sinus than the latter. It is referred to Tritonoturris DALL, 1924 on the basis of conformable characteristics, protoconch, anal sinus, strong basal contraction and bold and sharp axial ribs, except for shorter profile. In other words, the present species is an axially shorter form of Tritonoturris and is reasonably included in the latter. 
Polygyrate and diagonally cancellate protoconch and shallow anal sinus of Daphnella (Pleurotomella) itama Melvill (1909, p. 78, pl. 8, f. 24) suggest its identity to Tritonoturris. The present species is closely similar to Tritonoturris itama, but is distinguished from the latter, which has rather sharp peripheral angulation on the spire-whorls and distinct subsutural growth threads. The present species superficially similar to some species of Asperdaphne, for example to A. sepulta LASERON, but is readilly distinguished from the latter in having diagonally cancellated protoconch.

\section{genus Pagodidaphne gen. nov.}

type-species: Pagodidaphne colmani gen. et sp. nov.

Diagnosis.-Shell minute and broadly fusiform. Protoconch polygyrate (3.5 volutions); the first volution spirally striated and remainder ones diagonally cancellated. Teleoconch-whorls sharply angulated between flat shoulder slope and vertical lateral surface. Body whorl about three-fourths of shell-height and moderately contracted at the base. Spiral lirae on the lateral and basal surface. Anal sinus moderately shallow reversed L-shaep below suture.

Comparison.-The present genus is characteristic with Fulgoraria-like broad fusiform shell with only spiral sculpture, polygyrate and diagonally cancellated protoconch, long and broad aperture with undifferentiated canal and moderately shallow daphnellid sinus. It is somewhat similar to Microgenia LASERON, 1954, but the former has longer base, shallower anal sinus, and conical protoconch with more numerous volutions than the latter. Furthermore, the former is devoid of spirals on the shoulder slope.

Teretia Monterosato, 1890 , is another ally to the present taxon, but the former has turreted spire and distinctly contracted base instead of biconically broad fusiform of the latter.

Pagodidaphone colmani gen. et sp. nov.

Pl. 2, Figs. 3 and 4, Text-fig. 7

Material.-holotype: C 134667 from approximately 100 miles north of Croker Island ( $\left.9^{\circ} 30^{\prime} \mathrm{S}, 132^{\circ} 34^{\prime} \mathrm{E}\right)$, Northern Territory. Depth, $124 \mathrm{~m}$. P. H. ColmaN coll. Nov. 9, 1969.

\begin{tabular}{lccccccc}
\multicolumn{2}{c}{ Measurements. } & & & & & \\
specimen & $\mathrm{H}$ & $\mathrm{Bd}$ & $\mathrm{W}$ & $\mathrm{Bd} / \mathrm{H}$ & $\mathrm{W} / \mathrm{H}$ & \multicolumn{2}{c}{ whorls } \\
C 134667 & 5.40 & 3.95 & 2.05 & 73.1 & 38.0 & 3.6 & 3.3
\end{tabular}

Diagnosis.-The same as the generic diagnosis.

Description.-Diagonal cancellation on the protoconch consists of opisthocyrt and opisthocline thin axial threads and opisthocyrt and prosocline ones of which the latter is restricted to the lower two-thirds of each volution. Boundary between the protoconch and teleoconch is rather sharp. The teleoconch starts with prominent two spiral cords on angulations. Development of spiral cords is adapical so that spirals are counted four on the second whorl. Secondaries are inter- 
calated on the third whorl. Spirals of primary order are 18 on the body whorl. Suture is simply impressed. Shoulder slope is practically devoid of strong spirals except for weak ones and is provided with distinct growth threads. Interspaces between spiral cords and lirae on the lateral surface are provided with dense microgranules formed by microspiral and axial lines. Aperture is elongate pyriform with undifferentiated, widely open and terminally truncated canal. Inner lip with thin callus. Labrum is thin at the edge. Anal sinus is shallow reversed L-shape on the shoulder slope. The lower arm of the sinus is swung forward and then abruptly curved on and around the peripheral angulation, below which it is vertical.

Comparison.-Daphnella annulata THIELE from the station 193 (1925, p. 216, pl. 28, f. 13) is referred to Pagodidaphne on the basis of its general profile, protoconch, anal sinus and pattern of the sculpture. The present species resembles Pagodidaphne annulata, but is distinguished from the latter in having larger shell with finer and more numerous spirals.

genus Austrodaphnella LASERON, 1954

type-species: Austrodaphnella clathrata LASERON, o. d.

Austrodaphnella torresensis sp. nov.

Pl. 2, Fig. 5, Text-fig. 5

Material.-holotype: C 134682a from off Murray Islands, Torres Strait, Queensland. Depth, 9-15 m. C. HedLeY coll. Paratypes, C 134682b and c, from the same locality as the holotype. Holotype is broken at the lower part of aperture and the others are more or less imperfect.

Measurements.-

\begin{tabular}{|c|c|c|c|c|c|c|c|}
\hline specimen & $\underset{(\mathrm{mm})}{\mathrm{H}}$ & $\underset{(\mathrm{mm})}{\mathrm{Bd}}$ & $\underset{(\mathrm{mm})}{\mathrm{W}}$ & $\begin{array}{c}\mathrm{Bd} / \mathrm{H} \\
(\%)\end{array}$ & $\begin{array}{l}\mathrm{W} / \mathrm{H} \\
(\%)\end{array}$ & \multicolumn{2}{|c|}{$\begin{array}{l}\text { whorls } \\
\text { proto. teleo. }\end{array}$} \\
\hline C 134682a & $3.25+$ & $2.20+$ & 1.40 & $67.7-$ & $43.1-$ & 2.8 & 3.0 \\
\hline C $134682 b$ & $5.15+$ & $3.20-$ & 2.30 & $62.1-$ & $44.7-$ & 3.2 & 3.5 \\
\hline
\end{tabular}

\section{Explanation of Plate 1}

Fig. 1. Vepridaphne cestrum (HEDLEY), gen. nov. ................... 18 C 134691, front view, $\times 16.1$

Figs. 2-5. Graciliclava mackayensis gen. et sp. nov. ............. 11 2 and 3. holotype, C 134685, front view (2) and side view (3), $\times 7.7$. 4 and 5. paratype, C 134680 , front view (4) and side view (5), $\times 7.7$.

Fig. 6. Philbertia (Glyphostomoides) queenslandica subgen. et sp. nov. holotype, C 134681 , front view, $\times 12.5$.

Figs. 7 and 8. Paradrillia (Paradrillia) darnleysisis sp. nov. ....... Page 4 holotype, C 61502, side view (7) and front view (8), $\times 7.4$.

Figs. 9 and 10. Horaiclavus (Anguloclavus) multicostatus (SCHEPMEN) ..... ................................................... 10 C 134663, front view (9) and side view (10), $\times 4.9$

Figs. 11 and 12. Ariella (Vexiariella) cancellata subgen. et sp. nov. .. Page 6 holotype, C 134664, front view (11) and side view (12), $\times 8.5$ 
Mem. Fac. Sci., Kyushu Univ., Ser. D, Vol. XXV

Plate 1

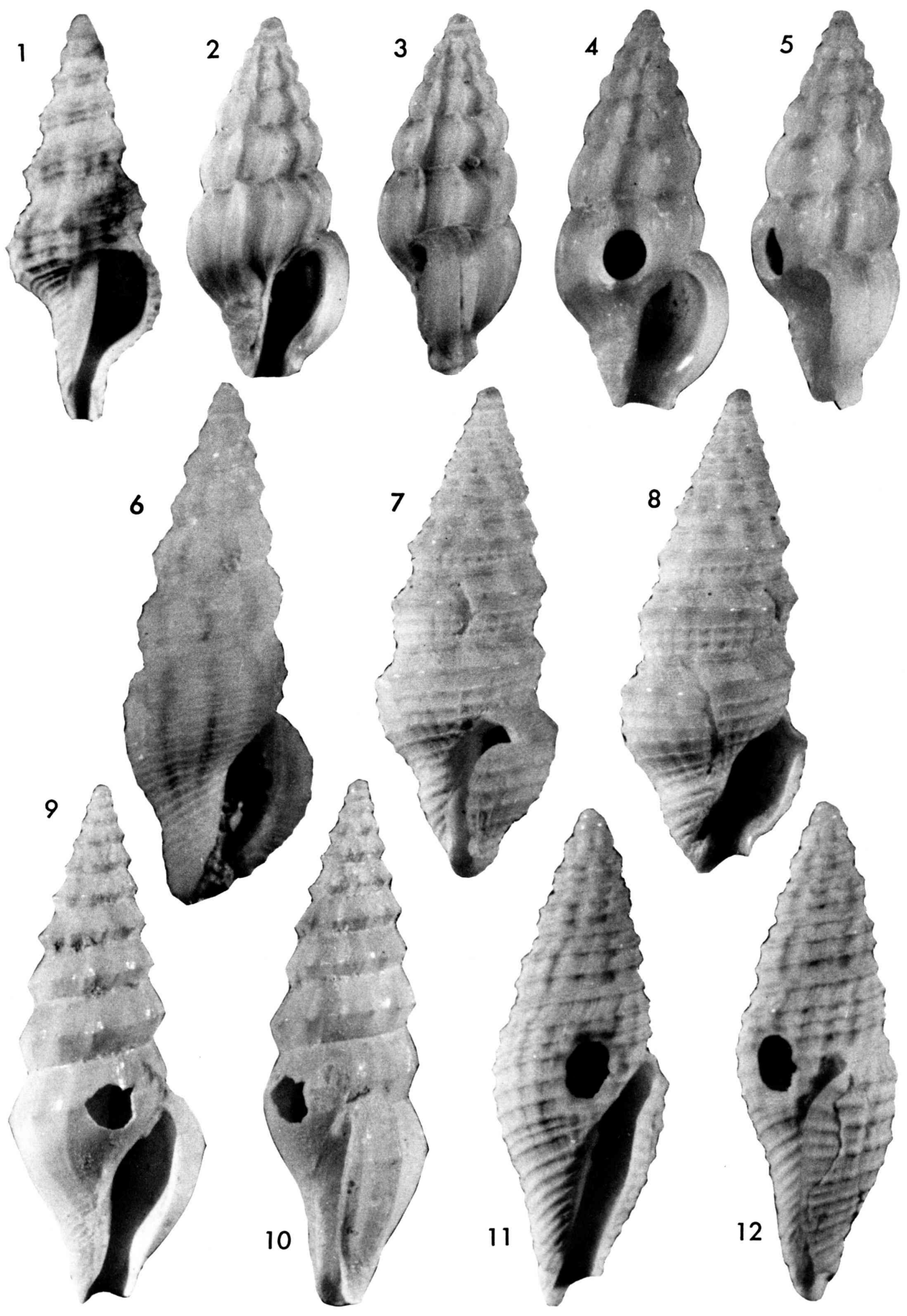

T. Shuto: Australian Turrids 

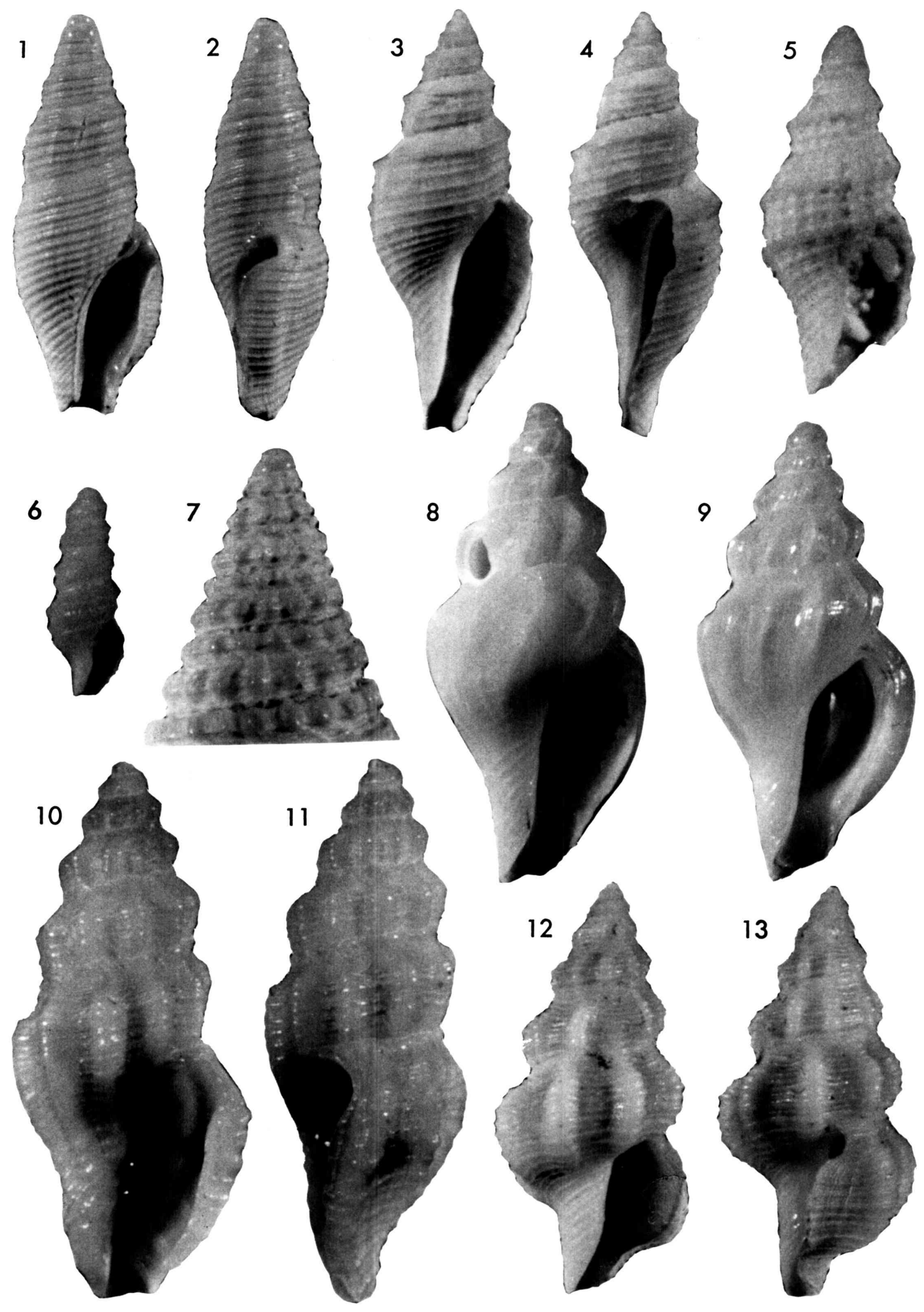

8
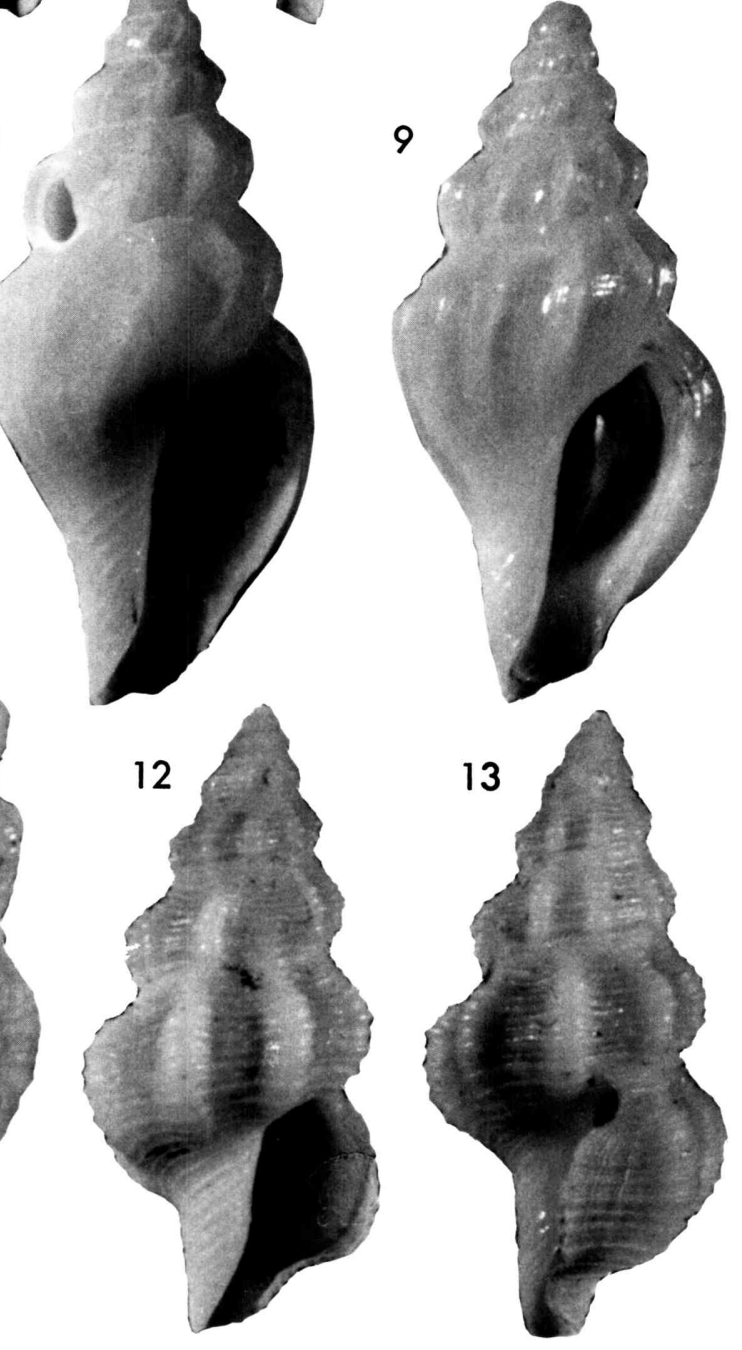

T. Shuto: Australian Turrids 
Diagnosis.-Shell minute and fusiform. Protoconch polygyrate and diagonally cancellated. Teleoconch-whorls peripherally angulated and provided with crude cancellation. Axials erected, rather thin and abruptly bent on the angulation. Upper arms above the angulation opisthocyrt, slightly opisthocline and remarkably thinner than vertical lower arms. Intersections of axials and spirals granular. Spirals on lateral surface much larger than those on shoulder slope and basal surface. Anal sinus very shallow. Aperture elongately rhomboid with weakly differentiated canal.

Description.-Protoconch consists of about three volutions; tip is seemingly smooth, the following part, less than one volution, is provided with obsolete reticulation by regular spiral striae and irregularly spaced vertical striae and the remaining part is diagonally cancellated. Boundary between protoconch and teleoconch is sharply marked by sinusigera ridge. Teleoconch whorl begins with two spirals cords, one median and the other suprasutural. Axial riblets are added immediately after the appearance of the spirals. Axial ribs reach both to upper and lower sutures on the spire-whorls and they are faded out on the snout of the body whorl. Body whorl is divided by peripheral and basal angulations into three parts, shoulder slope, vertical lateral surface and gradually contracted basal surface. Spirals on the lateral surface, particularly those on the angulations are prominent. Anterior part of aperture is missing on all the specimens so that real length of canal can not be measured. Sinus is wide and imperceptibly shallow occupying the shoulder slope. Suture is impressed and remarkably oblique.

Comparison.--The present species is characteristic by its lateral band with conspicuously strong spirals, sharply bent axial ribs on the peripheral angula-

\section{Explanation of Plate 2}

Figs. 1 and 2. Austropusilla (Metaclathurella) crokerensis subgen. et sp. nov.

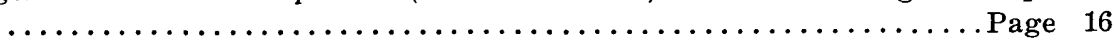
holotype, C 134692, front view (1) and side view (2), $\times 7.8$.

Figs. 3 and 4. Pagodidaphne colmani gen. et sp. nov. ............ Page 21 holotype, C 134667, front view (3) and side view (4), $\times 12.0$.

Fig. 5. Austrodaphnella torresensis sp. nov. ................ Page 22 holotype, C $134582 \mathrm{a}$, front view, $\times 17.8$.

Fig. 6. Pseudexomilus bicarinatus sp. nov. ............... Page 24 holotype, C 134679, front view, $\times 12.6$.

Fig. 7. Paradrillia (Coronacomitas) gemmata subgen. st sp. nov. ....Page 3 holotype, C 134694, apical part, $\times 11.5$.

Figs. 8 and 9 . Antiguraleus stellatomoides sp. nov. ...........Page 14 8. holotype, C $134686 \mathrm{a}$, front view, $\times 8.0$.

9. paratype, C $134686 \mathrm{~b}$, front view, $\times 8.0$.

Figs. 10 and 11 . Verithara brevicanalis sp. nov. ................. 8 holotype, C 134689, front view (10) and side view (11), $\times 12.2$.

Figs. 12 and 13. Tritonoturris buccinoides sp. nov. ..........Page 18 holotype, C 134673a, front view (12) and side view (13), $\times 9.3$. 
tion among a group of daphnellines with fusiform profile and crudely cancellated teleoconch sculpture. It is allied to Daphnella (Pleurotomella) alcestis Melvill (1906, p. 78, pl. 8, f. 23) from Persian Gulf in the general profile, protoconch, anal sinus and sculptural pattern, but is distinguished from the latter in having more crude sculpture, wider shoulder slope with distinct spirals and slightly concave lateral side.

It is similar to Austrodaphnella clathrata LASERoN (1954, p. 45, pl. 11, f. 228), but is readily distinguished from the latter by the lateral side mentioned above, wider shoulder slope with spiral cords and opisthocyrtly curved upper portion of the axials. It is a problem whether it is included in Austrodaphnella LASERoN, 1954 , or it represents a new subgenus or genus. It is, however, tentatively placed under the generic name of Austrodaphnella because all the specimens accessible are imperfectly preservd.

\author{
genus Pseudexomilus Powell, 1944 \\ type-species: Pseudexomilus caelatus Powell, o. d. \\ Pseudexomilus bicarinatus sp. nov. \\ Pl. 2, Fig. 6, Text-fig. 7
}

Material.-holotype: C 134679 from BMR Stn. P 69-872, off Bowen (19 $48^{\prime}$ S, $148^{\circ} 53^{\prime}$ E), Queensland. Depth, 62 m. Sept. 26, 1969.

\begin{tabular}{|c|c|c|c|c|c|c|c|}
\hline specimen & $\underset{(\mathrm{mm})}{\mathbf{H}}$ & $\underset{(\mathrm{mm})}{\mathrm{Bd}}$ & $\underset{(\mathrm{mm})}{\mathrm{W}}$ & $\begin{array}{c}\mathrm{Bd} / \mathrm{H} \\
(\%)\end{array}$ & $\begin{array}{l}\mathrm{W} / \mathrm{H} \\
(\%)\end{array}$ & $\begin{array}{c}\text { protoconch } \\
\text { vols. } \quad \mathrm{D}(\mathrm{mm})\end{array}$ & $\begin{array}{l}\text { teleoconch } \\
\text { whorls }\end{array}$ \\
\hline C 134679 & 2.25 & 1.40 & 1.00 & 54.9 & 39.2 & $\begin{array}{ll}1.9 & 0.50\end{array}$ & 2.1 \\
\hline
\end{tabular}

Diagnosis.-Shell fusiform minute and thin. Protoconch large, globose, paucispiral and distinctly axially lirated. Teleoconch spirally carinated and provided with coarse growth threads. Carinal ribs two on spire-whorls, three on lateral side of body whorl. Those on base remarkably weak. Aperture elongate pyriform with widely open, moderately long, and terminally truncated canal. Practically no anal sinus.

Descriptive remarks.-Protoconch is extremely large occupying about 16 percent of the total height of shell. Its axial lirae are also extremely coarse for a protoconch sculpture. Spire-whorls are sharply biangulate at the lower and the upper one-third of each whorl. Angulations are superimposed respectively with a distinct spiral lira. Suture is impressed with a weak subsutural lira on which irregularly spaced coarse growth threads make small granules. Between the growth threads are fine growth lines. Base and snout of the body whorl are encircled respectively with three and four spiral lirae, which are remarkably weaker than the peripheral ones. Basal contraction is distinct.

Comparison.-The present species is referred to Pseudexomilus Powell, 1944, on the basis of its characteristic protoconch and apertural feature. It is similar to $P$. costicapitata VerCo from South Australia, but is readily distinguished from the latter in that the present species has straight spirals instead of wavy ones of the latter. No other comparative species. 


\section{Storage}

All the specimens examined are stored in the Department of Malacology, The Australian Museum in Sydney.

\section{Works Cited}

Adams, A. (1867): Descriptions of new species of shells from Japan. Proc. Zool. Soc. London, 309-315, pl. 19.

ADAMs, H. (1869) : Descriptions of a new genus and fourteen species of marine shells. Ibid., 272-275, pl. 19.

Bartsch, P. and RehDer, H. A. (1939): New turrid mollusks from Florida. Proc. U.S. Nat. Mus., 87, (3070), 127-138.

DALL, W. H. (1889) : Reports of the results of dredging, under the supervision of Alexander Agassiz, in the Gulf of Mexico and in the Carribean Sea by the U. S. Coast Survey Steamer "Blake". Bull. Mus. Comp. Zool., 18, 1-492.

(1924) : Notes on molluscan nomenclature. Proc. Biol. Soc. Washington, 37, 87-90.

Finlay, H. L. (1926) : New shells from New Zealand Tertiary beds. Pt. 2, Trans. Proc. New Zealand Inst., 56, 227-258, pls. 55-60.

Fischer, P. J. (1927): Beitrag zur Kenntnis der Pliozänfauna der Molukken Inseln Seran und Obi. Paläont. v. Timor, (15), 1-179, Taf. 212-217.

GabB, W. M. (1873) : Descriptions of some new genera of Mollusca. Proc. Acad. Nat. Sci. Philadelphia, 24, 270-274.

Hedley, C. (1922): A revision of the Australian Turridae. Rec. Austr. Mus., 13, (6), 213-359, pls. $42-56$.

IREDALE, T. (1936): Australian molluscan notes. No. 2. Ibid., 19, 267-340, pls. 20-24.

Kuroda, T., Habe, T. and Oyama, K. (1971) : The Shells of Sagami Bay. 1-741 (1-489) +51 , pls. 1-120, Maruzen. Tokyo.

Laseron, C. F. (1954): New South Wales Turridae (Mollusca). Austr. Zool. Handb. Roy. Zool. Soc. N. S. W. 1-56, pls. 1-12.

Makiyama, J. (1940): Nomenclatural notes on some genera of Turridae. Trans. Palaeont. Soc. Japan, (102), 25-26.

Melvill, J. C. (1906) : Descriptions of thirty-one Gastropoda and one scaphopod from the Persian Gulf and Gulf of Oman, dredged by Mr. F. W. Townsend, 1902-1904. Proc. Malac. Soc. London, 7, 69-80, pls. 7-8.

(1917): A revision of the Turridae (Pleurotomidae) occurring in the Persian Gulf, Gulf of Oman, and north Arabian Sea, as evidenced mostly through the results of dredgings carried out by Mr. F. W. Townsend, 1893-1914. Ibid., 12, 140-201, pls. 8-10.

and Standen, R. (1901): The Mollusca of the Persian Gulf, Gulf of Oman and Arabian Sea as evidenced mainly through the collection of Mr. F. W. Townsend 1883-1900, with descriptions of new species. Proc. Zool. Soc. London, $327-460$, pls. $21-24$.

and (1906): The Mollusca of the Persian Gulf. Gulf of Oman and Arabian Sea as evidenced mainly through the collection of Mr. F. W. Townsend 1883-1900, with descriptions of new species. Ibid. 783-848, pls. 53-56.

Monterosato, T. A. di (1884): Nomenclatura Generica e Spezifica di Alcune Conchiglie Mediterranee. pp. 155. Palermo. (non vidi)

(1890): Conchiglie della profundita del mare di Palermo. Naturalista Sicili, 9, 181-191. (non vidi)

Oliver, W. R. B. (1915): The Mollusca of the Kermadec Islands. Trans. Proc. New Zealand Inst., 47, 509-568, pls. 9-12.

Powell, A. W. B. (1942): The New Zealand recent and fossil Mollusca of the Family Turridae, with general notes on turrid nomenclature and systematics. Bull. 
Auckland Inst. Mus. (2), 1-192, pls. 1-14.

(1944) : The Australian Tertiary Mollusca of the Family Turridae. Ibid. (3), 1-68, pls. 1-7.

(1966): The molluscan Family Speightiidae and Turridae. An evaluation of the valid taxa, both Recent and fossil, with lists of characteristic species. Ibid. (5), 1-184, pls. 1-23.

(1969): The Family Turridae in the Indo-Pacific. Pt. 2. The subfamily Turriculinae. Indo-Pacific Moll., 2, (10), 207-416, pls. 188-324.

Reeve, L. A. (1843) : Conchologia Iconica 1, Pleurotoma 40 pls. 369 spp. London. (1845) : Ibid., 3, Mangilia, 8 pls, 71 spp. London.

SchepmaN, M. M. (1913) : Prosobranchia of the Siboga Expedition. Siboga Expeditie Monogr. (49), Part 5, 365-452, pls. 25-30.

Shasky, D. R. (1961): Notes on rare and little known Panamic mollusks. Veliger, 4, (1), 22-24, pl. 4 .

Shutc, T. (1965): Turrid gastropods from the Upper Pleistocene Moeshima Shell Bed. (Molluscan Palaeontology of the Pleistocene Formations in Kyushu-1). Mem. Fac. Sci., Kyushu Univ. Ser. D, Geol., 16, (2), 143-207, pls. 29-35.

(1969): Neogene gastropods from Panay Island, the Philippines. Ibid., 20, (1) , 1-250, pls. 1-24.

Sмiтh, E. A. (1879): On a collection of Mollusca from Japan. Proc. Zool. Soc. London, 181-218, pls. 19-20.

TAKI, I. and OYAMA, K. (1954): Matajiro Yokoyama's the Pliocene and later faunas from the Kwanto region in Japan. Palaeont. Soc. Japan., Spec. Pap. (2), 1-68, pls. 1-49.

Thiele, J. (1925) : Gastropoda der Deutschen Tiefsee-Expedition II. Teil. Wissensch. Ergebn. Deutsch. Tiefsee-Exped. auf dem Dampfer "Valdivia" 1898-1899. Zool., 16, (2), 1-348, Taf. 1-34.

Verco, J. C. (1909): Notes on South Australian marine Mollusca, with descriptions of new species. Pt. II. Trans. Roy. Soc. S. Austr., 33, 277-292.

VERRILL, A. E. (1873) : Brief contributions to zoology.-Results of recent dredging expeditions on the coast of New Zealand. Amer. Jour. Sci., Ser. 3, 5, 1-16, and 89-106.

Weinkauff, J. C. und Kobelt, W. (1887): Die Familie Pleurotomidae in Martini und Chemnitz. Systematischen Conchylien Cabinet. 4, (3), 1-248, Taf. 1-42.

Woodring, W. P. (1928): Miocene mollusks from Boden, Jamaica. Pt. 2 . Publ. Carnegie Inst. Washington, (385), 1-459, pls. 1-40.

Yokoyama, M. (1923): Tertiary Mollusca from Dainichi in Totomi. Jour. Coll. Sci. Imp. Univ. Tokyo, 45, (2), 1-18, pls. 1-2. 